Anna Kotłowska (Poznań)

(iD) https://orcid.org/0000-0002-6547-806X

\title{
LOVE AND THEATRE IN THE WORKS OF NIKEPHOROS BASILAKES*
}

\section{Introduction}

In

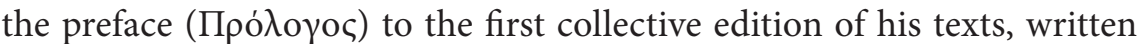
at the end of his life as à mi-chemin entre l'autobiographie et le 'manifeste' littéraire ${ }^{1}$, Nikephoros Basilakes (ca. 1115 - after 1182)² modifies the quote from Meditations by Marcus Aurelius in a way that would prove essential for the understanding of the emotional dimension of his work:

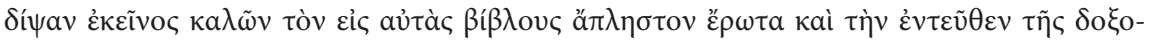

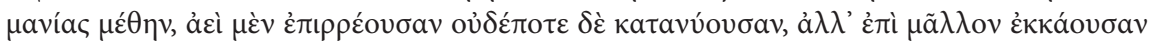

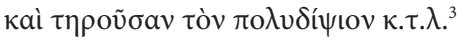

* This paper is an extended version of a lecture presented on 1 March 2018 at University of Łódź Ceraneum Centre. I would like to thank the organizing committee for inviting me to attend this important event. I would also like to take this opportunity to express my gratitute to Carolina Cupane (Vienna) for kindly sharing with me hard-to-find studies.

${ }^{1}$ A. GarzYa, Un lettré du milieu du XII siècle: Nicéphore Basilakès, RESEE 8, 1970, p. 615; IDEM, Intorno al Prologo di Niceforo Basilace, JÖB 18, 1969, p. 57-71, but only with the amendment by I.D. Polemis, A Note on the Praefatio of Nikephoros Basilakes, BZ 94, 2001, p. 605-607.

${ }^{2}$ A. Garzya, Precisazioni sul processo di Niceforo Basilace, B 40, 1970, p. 309-316; IDEM, Un lettré...; IDEM, Fin quando visse Niceforo Basilace?, BZ 64, 1971, p. 301-302; IDEM, Literarische und rhetorische Polemiken der Komnenenzeit, Bsl 34, 1973, p. 1-14; IDEM, Il "Prologo" di Niceforo Basilace, BCPENCGL n.s. 19, 1971, p. 55-71.

${ }^{3}$ Nikephoros, Praef., I, [in:] Nicephori Basilacae Orationes et Epistulae, ed. A. Garzya, Leipzig 1984 (cetera: ed. Garzya), p. 1-2. Riccardo Maisano wrote about this edition (in: Antonio Garzya bizantinista, [in:] L'Antico e la sua eredità. Atti del Colloquio internazionale di studi in onore di Antonio Garzya (Napoli, 20-21 settembre 2002), ed. U. Criscuolo, Napoli 2004, p. 196): Accanto agli interessi protobizantini, si colloca, per importanza e risonanza nella storia degli studi, una fitta serie di ricerche pionieristiche nel campo della grande retorica dell' età dei Comneni, e in particolare sull'opera del retore Niceforo Basilace, con edizioni commentate degli scritti, pubblicate e interpretate a piú riprese e culminate con la editio dell intero corpus delle orazioni nella Biblioteca Teubneriana (1984). 


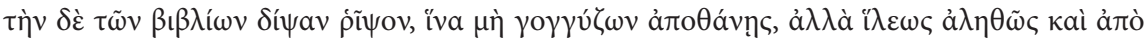

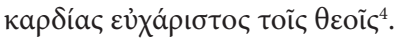

Let these reflections suffice thee, if thou hold them as principles. But away with thy thirst for books, that thou mayest die not murmuring but with a good grace, truly and from thy heart grateful to the Gods ${ }^{5}$.

Let this be enough for you, and your constant doctrine. And give up your thirst for books, so that you do not die a grouch, but in true grace and heartfelt gratitude to the gods ${ }^{6}$.

Writing about the excessive desire for book knowledge, Basilakes does not

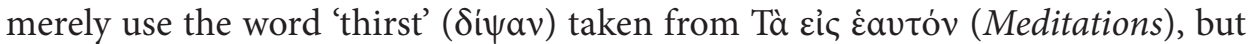
expands it and at the same time reinforces with the phrase ä $\pi \lambda \eta \sigma \tau o v$ है $\rho \omega \tau \alpha$ ('insatiable desire'). This wording, emotionally charged and surprising in the light of Byzantine aesthetics, seems to reflect the author's creative personality. The use of the word 'eros' outside strictly sexual semantics is in itself very interesting: it indicates the writer's psychological interests, his emotional involvement, and, at the same time, the strength of his character, as he did not hesitate to write explicitly about matters that were only inferred through metaphors at the time. Therefore, even if we assume that the above phrases are a sophisticated topos

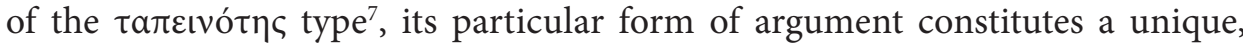
authorial sphragis ${ }^{8}$. We believe that by exploring this particular aspect of the language of emotion that Nikephoros uses we will overcome the limitations of the aesthetic norms of the time, come closer to the real discussion about the human condition that took place within the literati circles of the era, and demonstrate the links between Nikephoros Basilakes' work and the recently reborn romance ${ }^{9}$.

${ }^{4}$ The Meditations of the Emperor Marcus Antoninus, II, 3, 1, 7-9, ed. et trans. A.S.L. Farquharson, Oxford 1944 [repr. Oxford 1968].

${ }^{5}$ The Communings with Himself of Marcus Aurelius Antoninus, ed. et trans. C.R. HaInes, LondonNew York 1916 [= LCL, 58], p. 29.

${ }^{6}$ Marcus Aurelius, Meditations, trans. M. Hammond, London 2006 [= Pcl], p. 11.

${ }^{7}$ I am not able to acquire too much knowledge, cf. Gregorius Nyssenus, De mortuis non esse dolendum, [in:] Gregorii Nysseni opera, vol. IX.1, ed. G. HeIL, Leiden 1967, p. 35, 1. 18 ('intellectual weakness'); Xenophon, Hellenica, III, 5, 22, [in:] Xenophontis opera omnia, vol. I, ed. E.C. Marchant, Oxonii 1900 [repr. Oxonii 1968] ('mental incapacity to fight'). Cf. C. Wendel, Die TAПEINOTH des griechischen Schreibermönches, BZ 43, 1950, p. 259-266 (rich collection of adjectives).

${ }^{8}$ Unlike the literature of Antiquity (example of a model study: O. ThÉvenAz, Auctoris nomina Sapphus: noms et création d'une persona littéraire dans l'Héroïde XV ovidienne, [in:] Onomastique et intertextualité dans la littérature latine. Actes de la journée d'étude tenue à la Maison de l'Orient et de la Méditerranée - Jean Pouilloux, le 14 mars 2005, Lyon 2009 [= CMOMA.SP, 41], p. 121-142), the above issues have not yet been systematically researched in the field of Byzantine studies.

${ }^{9}$ Of the four works written in the Age of the Komnenoi (see below), one should exclude the novel by Constantine Manasses (ca. 1115-ca. 1187), preserved in fragments, titled Aristandros and Kallithea. It was written circa 1160, and thus long after Basilakes had finished his artistic career (see below, although Eros appears in a dozen or so fragments; the aspect of personal travel experiences that 


\section{"Insatiable Desire"}

The phrase ä $\pi \lambda \eta \sigma \tau o \varsigma ~ \varepsilon ै \rho \omega \varsigma$ appears in a work ${ }^{10}$ entitled A Story ${\text { [diegema] }{ }^{11} \text {, also }}_{\text {told by Plutarch in the Parallel Lives }}^{12}$. It tells the story of the Lydian king Pythes,

influenced the narrative in his novel was presented by Catia Galatariotou, Travel and Perception in Byzantium, DOP 47, 1993, p. 221-241), see Der Roman des Konstantinos Manasses. Überlieferung, Rekonstruktion, Textausgabe der Fragmente, ed. O. Mazal, Wien 1967 [= WBS, 4]; H. Hunger, Die hochsprachliche profane Literatur der Byzantiner, vol. II, München 1978 [= HA.BH, 12.5], p. 126-128; P. Magdalino, In Search of the Byzantine Courtier: Leo Choirosphaktes and Constantine Manasses, [in:] Byzantine Court Culture from 829 to 1204, ed. H. Maguire, Washington 1997, p. 161-165.

${ }^{10}$ Niceforo Basilace, Progymnasma, XI, [in:] Niceforo Basilace, Progimnasmi e monodie, ed. A. Pignani, Napoli 1983 [= BNN, 10] (cetera: ed. Pignani), p. 82-85, 270-272; Nikephoros BasiLAKes, Narration, IV, [in:] The Rhetorical Exercises of Nikephoros Basilakes. Progymnasmata from Twelfth-Century Byzantium, ed. et trans. J. Beneker, C.A. Gibson, London-Cambridge Mass. 2016 [= DOML, 43] (cetera: ed. BENEKER - GiBSON), p. 24-29. The author of the last publication had also included some corrections and emendations suggested in published reviews, some of them proposed themselves, but had not personally inspected the manuscripts.

${ }^{11}$ Diegema (Latin narratio) is the simplest form of rhetorical expression, understood as 'an account, a story'. Depending on the environmental context, it may be ethically charged (e.g. in the hagiography analyzed by C. RAPP: Storytelling as Spiritual Communication in Early Greek Hagiography: The Use of Diegesis, JECS 6, 1998, p. 431-448), although it is not a requirement ex definitione. Such require-

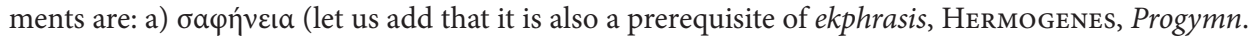
X, 23-24, [in:] Hermogenis opera, ed. H. Rabe, Lepzig 1913, p. 23; Diogenes Laertius, Lives of Eminent Philosophers, VII, 59, vol. II, trans. R.D. Hicks, Cambridge Mass.-London 1925 [= LCL,

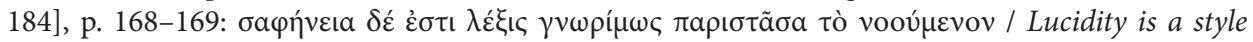

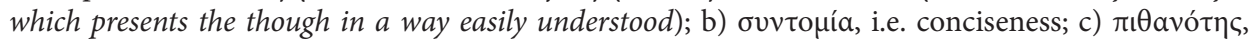
i.e. plausibility. There is no doubt that Basilakes' Diegemata possesses all these qualities, but let us specify that pithanotes in this case means the internal cohesion of the world presented in the work, and not the objective probability of events. In other words, it also includes the narrative of the world of myth in full, if its heroes act according to the internal laws of this world (the definition above is universal and refers to the whole Greek Antique and Byzantine literature, and allows to avoid thinking with the simple contemporary true-false dichotomy, cf. J.R. Morgan, Make-Believe and Make Believe: the Fictionality of the Greek Novel, [in:] Lies and Fiction in the Ancient World, ed. C. GILL, T.P. Wiseman, Exeter 1993, p. 175-229; Greek Fiction, ed. J.R. Morgan, R. Stoneman, LondonNew York 1994 (including the article by S. MacAlister, Byzantine Developments, [in:] Greek Fiction..., p. 275-287). Diegema is usually synonymous with diegesis, although Nikolaos the Sophist and Aphthonios treated the latter as a broader-spectrum narrative concept, while the diegema is specific (see C. RAPp, Storytelling as Spiritual..., p. 433, footnote 2), in fact, however, it is a highly individual issue, e.g. Gerontius (saec. V), Vita S. Melaniae Junioris, I, 1, 16, [in:] Vie de Sainte Mélanie, trans.

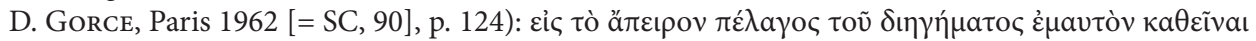

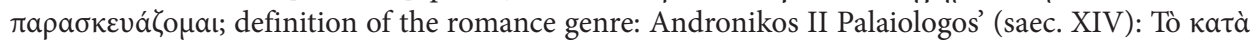

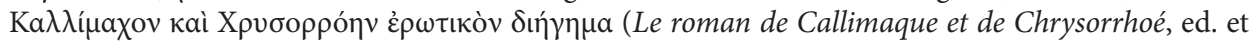

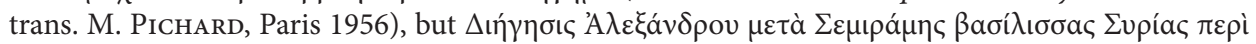

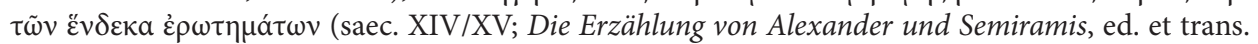
U. Moennig, Berlin-New York 2004 [= SB, 7]).

${ }^{12}$ Niceforo Basilace, Progymnasma, XI, ed. Pignani, p. 82-85. For the English version of the article, I used the translation by J. Beneker and C.A. Gibson, however the title proposed by Sophia Xenophontos sounds better: Narrative (diegema), also mentioned by Plutarch in the Parallel Lives, see below. 
a good ruler, who, however, was overcome by a desire for gold so great that it slowly destroyed him. Several years ago, Sophia Xenophontos demonstrated that Basilakes' narrative is based on Plutarch's story ${ }^{13}$ and collected the classical tradition of myth ${ }^{14}$. The title is misleading because Plutarch recounts the story in Mulierum virtutes 262D-263A, but it is nevertheless easily explained: Moralia, of which Mulierum virtutes is a part, was not collected in a separate edition until the time of Maximus Planudes and was often treated as part of the much more popular Vitae parallelae ${ }^{15}$. At this point, however, let us return to the lexicon that defines Pythes' mental state in relation to gold.

Already at the outset we learn that Pythes as a king was beyond reproach, except

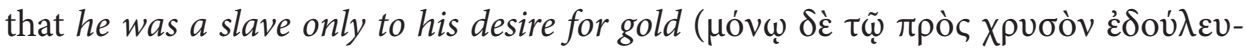
$\varepsilon v \varepsilon \varepsilon \rho \omega \tau \iota)$, but was otherwise a reasonable man ( $\left.\tau \alpha{ }^{\prime} \lambda \lambda \alpha \sigma \omega \varphi \rho o v \tilde{\omega} v\right)$. It is interesting that Basilakes considers the Lydian ruler's case from a psychiatric perspective,

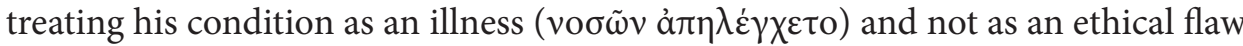
of character. The impression that it is not really about gold, that it is not a question of greed, but rather a pathological need to be satisfied, in which the precious metal plays the role of an artifact of secondary importance (nowhere in the text, despite the accumulation of several dozen derivatives of the term $\chi \rho v \sigma o$ c, is there any allusion to its material value or Pythes' avarice), is made more likely when the characteristics of the figure in question concludes with the following line: [...] as all their [i.e. subjects] efforts were directed toward fulfilling the desire of their ruler

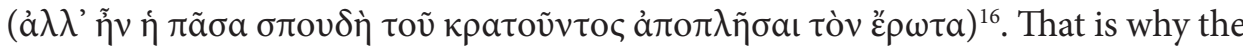
cure, prepared by his wife, whose name is unfortunately never mentioned, proves successful: when Pythes, weary and hungry, returned from the hunt, he was only given golden food, served on golden plates on golden tables... A strong biological need managed to overcome his soul's illness.

\footnotetext{
${ }^{13}$ As a result, we must reject the opinion of the Nikephoros' publisher, Adriana Pignani, who in Progymnasma, XI (Narration, IV, ed. BeneKeR - GiBson, p. 24-29) noted only a variation of the Midas myth, p. 16, note 8: [...] Il titolo ne riconosce la fonte in un supposto analogo dieghema, compreso nelle Vite parallele di Plutarco, ma con un falso evidente, ché il racconto plutarcheo non é. Trattasi invece d’un rifacimento abbastanza originale del diffusissimo mito del re Mida.

${ }^{14}$ S. Xenophontos, Resorting to Rare Sources of Antiquity: Nikephoros Basilakes and the Popularity of Plutarch's Parallel Lives of Twelfth-Century Byzantium, Par 4, 2014, p. 1-12.

${ }^{15}$ Ibidem, p. 10-12.

${ }^{16}$ Nikephoros Basilakes, Narration, IV, ed. Beneker - Gibson, p. 25. The Xenophontos translaton: [...] their ruler's every effort was dedicated to satisfying his passion seems too delicate, whereas it is addmisible to change the sentence subject.
} 
In his ethopoeia ${ }^{17}$ What Heracles would say while serving as a slave to Omphale ${ }^{18}$, Basilakes depicts the son of Zeus and Alcmene defeated by a more powerful force. In the past, Heracles complains, I have tried to be wise ( $\sigma \omega \varphi \rho \omega \dot{\omega})$ but I have always been caught by Eros, who overcame my senses and led me to misery. It is in this context that he utters several epithets that very unanimously emphasize the inevi-

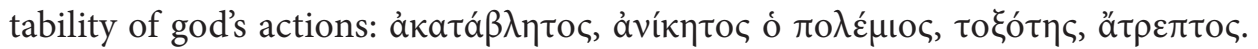
In his final prayer to Zeus and Athena, Heracles pleads with them to bring him back to his former condition ${ }^{19}$ :

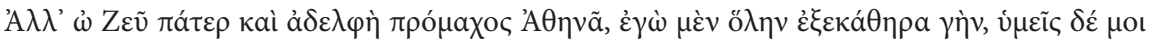

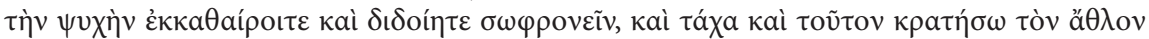

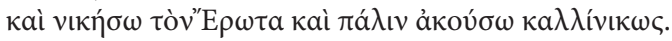

But $\mathrm{O}$ father Zeus and sister Athena, the protector, since I purged the entire earth, may you purge my soul and grant me to be soberminded: then perhaps I will also be victorious in this contest, will defeat Love, and will once again be called glorious champion.

Coincidentally, Nicetas Eugenianos referred to the same myth in a short text

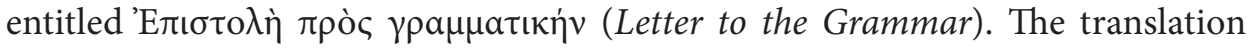
and commentary have been published elsewhere ${ }^{20}$, therefore let us only emphasize that Niketas is a lover ( $\pi \rho$ ò $\varsigma$ ) of his creative Muse (this is why he is able to write at all) and expresses his desire to write as follows: I have given myself to you [i.e. Grammar] into captivity like Heracles to Omphale.

\footnotetext{
${ }^{17}$ Ethopoeia is a rhetorical exercise in which one's own statement shows the personality of the speaker. "Imaginary Allocution" - as stated in the skillful but imprecise definition, as if on the margin of the main theme, by late R.J.H. Jenkins, The Hellenistic Origins of Byzantine Literature, DOP 17, 1963, p. 45 and much better: R.J. Penella, The "Progymnasmata" in Imperial Greek Education, CW 105,2011, p. 81 and note 20: "speech-in-character"; the article is a very good theoretical introduc-

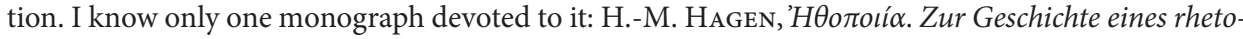
rischen Begriffs (Diss., Universität zu Erlangen-Nürnberg 1966). Recently a collection of studies has also been published: Ethopoiia. La représentation de caractères entre fiction scolaire et réalité vivante à l'époque impériale et tardive, ed. E. Амато, J. Schamp, Salerno 2005. Unfortunately, all of them concern Late Antiquity literature, as does the accessible essay by R. WebB, The Progymnasmata in Practice, [in:] Education in Greek and Roman Antiquity, ed. Y. LeE Too, Leiden-Boston 2001, p. 289-316. On the existence of early Christian ethopoeia, the existence of which was challenged not long ago even in textbooks, cf. J.-L. Fournet, Une éthopée de Caïn dans le Codex des Visions de la Fondation Bodmer, ZPE 92, 1992, p. 253-266.

${ }^{18}$ Niceforo Basilace, Progymnasma, XlViII, ed. Pignani, p. 197-199, 347-348; Nikephoros Basilakes, Ethopoeia, XIX, ed. Beneker - Gibson, p. 258-263.

${ }^{19}$ Nikephoros Basilakes, Ethopoeia, XIX, ed. Beneker - Gibson, p. 262-263.

${ }^{20}$ A. KoтŁowsкA, Herakles w bizantyńskiej refleksji poetyckiej. Studium przypadku, VP 35, 2015, p. 293-296.
} 
Interestingly, two writers of one generation (one of whom also the author of a romance) use the same, not particularly popular myth, to express their psychological sense of addiction. The most drastic approach, one whose realism appeals also to the contemporary audience, is the ethopoeia entitled What the girl from Edessa would say after being deceived by the Goth $?^{21}$ The man would not have been successful if it had not been for Eros' help (what is significant, it was expressed in militaristic terminology, in order to emphasize brutality) in overcoming the girl's areté2 ${ }^{2}$ :

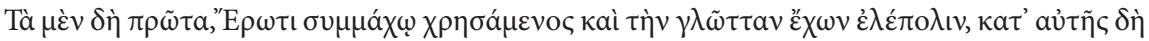

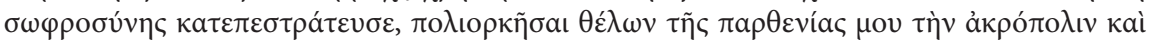

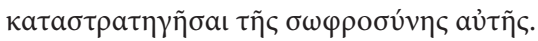

At first, then, employing Love as his ally and possessing a siege engine for a tongue, he led an assault against chastity itself, wishing to besiege the acropolis of my maidenhood and lead a campaign against my very chastity.

A similar vision of Eros as an external force that can lead to evil and certainly is suspicious had been suggested two hundred years earlier by John Geometres in an epitaph dedicated to John Tzimiskes ${ }^{23}$. The emperor, as persona loquens, tells the story of his life, including the following justification of the assassination of Nikephoros II Phokas:

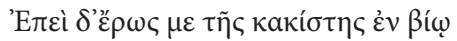

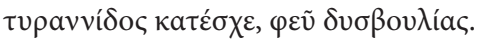

It is Eros, who has submitted my life to his tyrannical power,

that is the cause of this misery.

Even earlier, in the body of writings of Libanius of Antioch ${ }^{24}$ contains a surviving ethopoiea entitled What words would an eunuch utter to talk about his love? now identified as a work of Severus of Antioch ${ }^{25}$. In the context discussed

\footnotetext{
${ }^{21}$ Niceforo Basilace, Progymnasma, LVI, ed. Pignani, p. 228-232, 366-369; NikePhoros BasiLAKes, Ethopoiea, XXVII, ed. BeNeKer - Gibson, p. 322-329.

${ }^{22}$ Niceforo Basilace, Progymnasma, LVI, 20-22, ed. Pignani, p. 229; Nikephoros Basilakes, Ethopoiea, XXVII, 2, ed. BENEKER - GiBson, p. 324.

${ }^{23}$ IoAnnes Geometres, 267.22-269.19, [in:] Anecdota graeca, vol. IV, ed. J.A. Cramer, Oxford 1841.

${ }^{24}$ Libanius, Progymnasma, XI, [in:] Libanii Opera, vol. VIII, rec. R. Foerster, Lipsiae 1913 [= BSGR], p. 434-435.

${ }^{25}$ E. Amato, Lautore dell' Ev̉voũxoৎ ẻ $\rho \tilde{\omega} v$ (Ps.-Lib. ethop. 26 Foerster) ed il più antico frammento in millet di etopea d’autore, [in:] Approches de la Troisième Sophistique. Hommages à Jacques Schamp, vol. II, ed. E. Амato, A. Roduit, M. Steinrück, Bruxelles 2005 [= ColL, 296], p. 3-17.
} 
herein, the essential element is the phrase concluding the prayer to Eros: $\ddot{\eta} \pi \alpha \tilde{v}-$

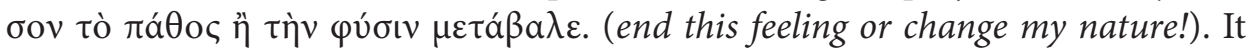
is a highly evocative expression of the They tellingly demonstrate the inability to cope with feelings on one's own and the inevitable conflict between human

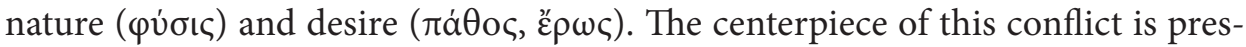
ent both in Basilakes' rhetorical writings as well as in his romances written for the purposes of theatron; the only difference is the way it is presented and interpreted.

Having laid groundwork, we can proceed to the myth which, like no other story, illustrates the ominous aspect of Eros, namely the myth of Pasiphaë. Basilakes wrote as many as two pieces on this subject, which so far have not been analysed separately ${ }^{26}$. They are not synonymous either, but rather mutually complementing ${ }^{27}$. Only in the first couple of sentences does the Story of Pasiphaë describe the nature of the Cretan ruler's feelings, without going into too many details ${ }^{28}$. Later, however, the text changes, gains pace, and the reason for this is expressed in a number of concise but emotionally charged phrases: the girl was compelled by Eros, who broke her character and forced her to do what she did not really want ${ }^{29}$. In the end, the narrative slows down again and speaks in a rather neutral - considering the circumstances - tone about Dedalus' invention and Minotaur's birth $^{30}$. Meanwhile, the ethopoeia What Pasiphaë would say after falling in love with a bull has to give the voice to the woman herself. This is conducive to a more nuanced content, including a broader argumentation. The main line of defense

\footnotetext{
${ }^{26}$ Only Antonio Garzya (Ovide, Nicéphore Basilakès et le mythe de Pasiphaé, L 26, 1967, p. 477-479) devoted two short texts to them, however, they focused on mythological material issues (the question of the identification of the material used for making the artificial cow) and Une rédaction byzantine du mythe de Pasiphaé, PI 9, 1967, p. 222-226 (factual similarities and differences with the Ovid's version).

${ }^{27}$ Niceforo Basilace, Progymnasma, XIX, ed. Pignani, p. 94-95, 277-278; Nikephoros BasiLakes, Narration, XII, ed. Beneker - Gibson, p. 46-49; Niceforo Basilace, Progymnasma, LIV, ed. Pignani, p. 221-224, 362-364; Nikephoros Basilakes, Ethopoeia, XXV, ed. Beneker - Gibson, p. 306-313.

${ }^{28}$ Niceforo Basilace, Progymnasma, XIX, 1-10, ed. Pignani, p. 94; Nikephoros Basilakes, Narration, XII, 1, ed. BENEKER - GIBSON, p. 47.

${ }^{29}$ Niceforo Basilace, Progymnasma, XIX, 10-20, ed. Pignani, p. 94-95; Nikephoros Basilakes,

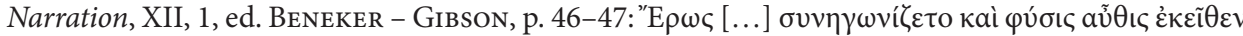

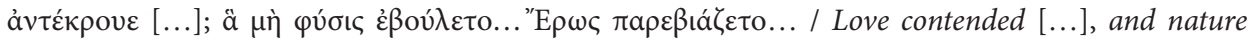
struck back from the opposing side... what nature rejected... Love strove to supply. J. BENEKER and C.A. Gibson translation is more gentle than the original.

${ }^{30}$ Niceforo Basilace, Progymnasma, XIX, 20-27, ed. Pignani, p. 94-95; Nikephoros Basilakes, Narration, XII, 2, ed. BeNEKer - GiBson, p. 46-49.
} 
is to invoke several "difficult loves" and to remind the old truth that human norms do not apply to gods ${ }^{31}$. Hence Pasiphaë can manifestly say ${ }^{32}$ :

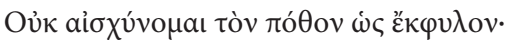

I'm not ashamed of this unnatural desire for another species.

It is only after this that she brings up the arguments that we already knew from the previous story: the violence of Eros, from whom there is no escape. That is why she is brave enough to cry out ${ }^{33}$ :

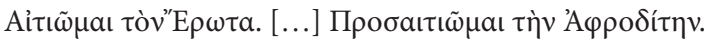

I find fault with Love. [...] I find fault with Aphrodite too ${ }^{34}$.

However, she does not ask for the spell to be reversed. It is an amazing scene: that is exactly how people should act in their dealings with gods. However, what impresses the audience the most is the conclusion: Pasiphaë controls herself and calmly asks Dedalus (what a suspense!) to speed up his work on the artificial heifer $^{35}$ : Unlike any other story, this tale shows the ethical limits of discourse and the extreme evil to which a god can contribute. It is only when a controversial subject emerges in literature that it is proof of its "cultural life". The antique and mythological setting, on the other hand, made it possible for the story, with its fundamentally amoral message ${ }^{36}$, to be published in the Empire. Pasiphaë shows that the issue of Eros was not only a rhetorical exercise, and that the avant-garde manner of her presentation saves her from being pigeonholed as part of the state "cultural program" 37 .

$$
* * *
$$

\footnotetext{
${ }^{31}$ Niceforo Basilace, Progymnasma, LIV, 1-31, ed. Pignani, p. 221-222, 362; Nikephoros Basilakes, Ethopoiea, XXV, 1-2, ed. Beneker - Gibson, p. 306-309. Cf. the fantastic words uttered by Eros in Niceforo Basilace, Progymnasma, LI, 29-30, ed. Pignani, p. 209, 354; Nikephoros

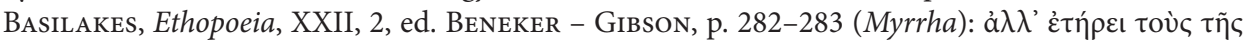

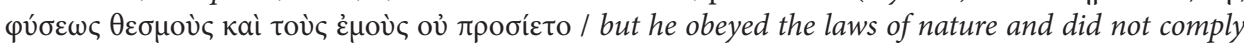
with mine.

${ }^{32}$ Niceforo Basilace, Progymnasma, LiV, 45, ed. Pignani, p. 223, 363; Nikephoros Basilakes, Ethopoiea, XXV, 4, ed. Beneker - Gibson, p. 310-311.

${ }^{33}$ Niceforo Basilace, Progymnasma, LIV, 56-57, ed. Pignani, p. 223, 363; Nikephoros BasiLAKES, Ethopoiea, XXV, 4, ed. BENEKER - GiBson, p. 310-311.

${ }^{34}$ I suggest here what seems to be a more accurate translation: I find fault with Aphrodite even more.

${ }^{35}$ Niceforo Basilace, Progymnasma, LiV, 84-90, ed. Pignani, p. 224; Nikephoros Basilakes, Ethopoiea, XXV, 6, ed. BeneKer - Gibson, p. 312-313.

${ }^{36}$ As it is not about Pasiphaës immoral act, but about a deity giving up morality.

${ }^{37}$ See below: discourse on the genesis of Eros' image in romance, some have fallen into this trap, mistaking form for content.
} 
Particularly noteworthy is the strong opposition of eros vs. $\sigma \omega \varphi \rho o \sigma v i v \eta$ (and

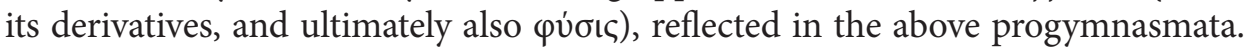
The very fact of choosing such an opponent calls for a commentary. $\Sigma \omega \varphi \rho o \sigma v i v \eta$

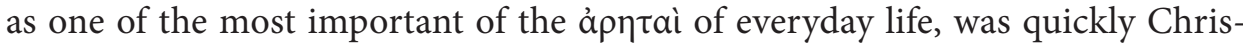
tianized and enjoyed great popularity in Byzantine literature of all ages, such as the Palaeologan era, even in works that were strongly influenced by the West ${ }^{38}$. Aristotle's definition in On Virtues and Vices has not lost its relevance either:

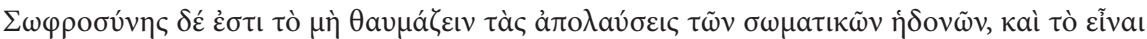

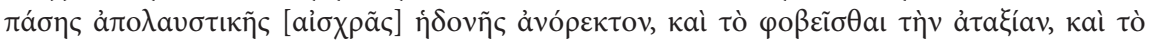

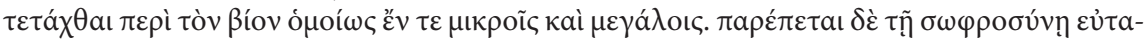

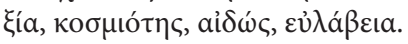

To sobriety of mind it belongs not to value highly bodily pleasures and enjoyments, not to be covetous of every enjoyable pleasure, to fear disorder, and to live an orderly life in small things and great alike. Sobriety of mind is accompanied by orderliness, regularity, modesty, caution $^{39}$.

This particular perception of Eros as a dark force or a sickness of the soul, which is extremely difficult for man to resist, turns our attention toward romances of its day, and consequently prompts us to ask about Basilakes' affiliation with the literary circle centered around the court (theatron, German: literarische Zirkel, French: cour littéraire $)^{40}$. The above issue has not been sufficiently

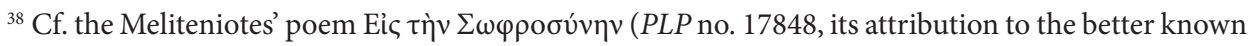
Theodore Meliteniotes [PLP no. 17851] is uncertain), edition: Poème allégorique de Méliténiote, ed. E. Miller, NEMBIAB 19, 2, 1872, p. 1-138 (extrait), cf. C. Cupane, Una passeggiata nei boschi narrativi. Lo statuto della finzione nel 'Medioevo romanzo e Orientale'. In margine a un contributo recente, JÖB 63, 2013, p. 84-90 (the author supports the authorship of Theodore).

${ }^{39}$ Aristotle, The Athenian Constitution. The Eudemian Ethics. On Virtues and Vices, trans. H. RackHAM, Cambridge Mass.-London 1952 [= LCL, 285], p. 492-493.

${ }^{40}$ A. Rнову, Verschiedene Bemerkungen zur Sebastokratissa Eirene und zu Autoren in ihrem Umfeld, NRh 6, 2009, p. 305-336; O. LAMPsIDIs, Zur Sebastokratorissa Eirene, JÖB 34, 1984, p. 91-105; E. JEFFREYs, The Sebastokratorissa Eirene as Literary Patroness: the Monk Iakovos, JÖB 32, 1982, p. 63-71; R. Dostálova, Die byzantinische Theorie des Dramas und die Tragödie Christos Paschon, JÖB 32, 1982, p. 73-83; M. Mullett, Aristocracy and Patronage in the Literary Circles of Comnenian Constantinople, [in:] The Byzantine Aristocracy, IX to XIII Centuries, ed. M. ANGold, Oxford 1984 [= BAR. IS, 221], p. 173-197 (in particular p. 175: translation of a fragment of a letter from Michael Italikos to Nikephoros Bryennios [to whom Prodromos dedicated his romance], Michael Italicus, Epistulae, XLIII, [in:] Michel Italikos, Lettres et discours, ed. P. Gautier, Paris 1972 [= AOC, 14], with information on the great impression made by the sent and read text of the latter "into logikon theatron"); EADEM, Rhetoric, Theory and the Imperative of Performance: Byzantium and Now, [in:] Rhetoric in Byzantium. 35 ${ }^{\text {th }}$ Spring Symposium of Byzantine Studies, ed. E. JefFreYs, Farnham 2003 [= SPBSP, 11], p. 151-160; M. GrünbarT, Female Founders - Das Konzept: Zu Stiftungshandlungen in der Byzantinischen Welt, WJK 60, 2012, p. 21-28; E.C. Bourbounakis, Rhetoric and Performance, [in:] The Byzantine World, ed. P. StePhenson, London-New York 2010, p. 175-187; P. MarciniaK, Byzantine
} 
examined $^{41}$; biographical data indicate that his contacts with the literati associated with the circle may have taken place in $1140-1155^{42}$, although researchers usually confine themselves statements that, while beautiful, are only very general in nature ${ }^{43}$.

Theatron - A Place of Performance?, [in:] Theatron. Rhetorische Kultur in Spätantike und Mittelalter / Rhetorical Culture in Late Antiquity and the Middle Ages, ed. M. GRüNBART, Berlin-New York 2007 [= Mil.S, 13], p. 277-285. It is therefore not surprising that theatron is not even mentioned in the critical bibliographic review devoted to the continuation of classical theatre (which began with

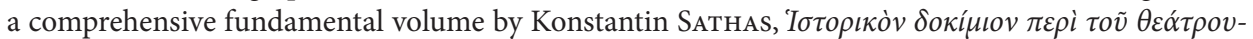

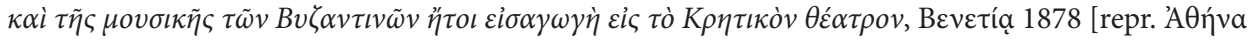
1979]), see: W. Puchner, Zum "Theater" in Byzanz, [in:] Fest und Alltag in Byzanz, ed. G. Prinzing, D. Simon, München 1990, p. 11-16 and p. 169-179 (notes); P. Magdalino, The Empire of Manuel I Komnenos, 1143-1180, New York 1993, p. 336-356, 429-434.

${ }^{41}$ In one of the letters (No. XIX, in: ed. GaUtier) Michael Italikos complains that the emperor favours one notary (votápısc) Basilakios (it is worth noting that research into the rhythm of Nikephoros' prose indicates that the clauses are very similar to those of Michael): R. MAISANo, La clausola ritmica nella prosa di Niceforo Basilace, JÖB 25, 1976, p. 87-104, the study was supplemented by W. Hörandner, Der Prosarhythmus in der rhetorischen Literatur der Byzantiner, Wien 1981 [= WBS, 16], p. 84-91: This level of creativity was neither a field of competition nor a formal experiment

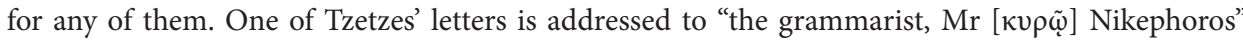
(IoAnnes Tzetzes, Epistulae, C, ed. P.L. LeOne, Leipzig 1972 [= BSGR], p. 146-147). However, the content does not provide sufficient grounds for closer identification (forsitan Leone is simply inconclusive). Nikephoros went through all levels of his career at the school at the Hagia Sophia, up to

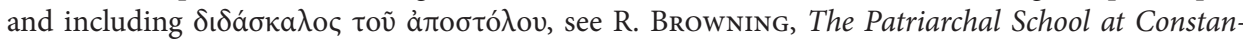
tinople in the Twelfth Century, B 32, 1962, p. 181-184. Thanks to his position and rhetorical skills, he prepared official speeches (including panegyrics) for the court. His scholarly and ecclesiastical career was abruptly interrupted by his involvement in a theological controversy concerning the eucharistic sacrifice in the context of Trinitarian issue. In the end, at a second synod on this issue, on May 12, 1157, Nikephoros' views were deemed unorthodox, and he himself was forced into exile. He settled in the Bulgarian Filipopol. It was then that the monody in memory of brother Constantine was composed, the last of his texts to be preserved, cf. A. GARzYA, Un lettré..., p. 613-615; Niceforo Basilace, Monodia, I, [in:] ed. Pignani, p. 235-252, 373-382. Several years ago Michael Grünbart called for a comprehensive and systematic study of the social relations and cultural ties of the representatives of the cultural elite in the $12^{\text {th }}$ century, which would have been possible due to the extensive body of sources, including correspondence. In his diagrams, which show the links between John Tzetzes (in this case, there is a good article by Andreas Rнову about the patronage strategy of this author: Ioannes Tzetzes als Auftragsdichter, GLB 15, 2010, p. 155-170) and Teodore Prodromos (the critical edition, to be published as the $81^{\text {st }}$ volume of CC.SG: Theodori Prodromi Epistulae et Orationes, Turnhout 2018, edited by Michiel D.J. Op DE Coul will certainly contribute to the research; however, in the short review by the author: The Letters of Theodore Prodromus and Some Other $12^{\text {th }}$ Century Letter Collections, MG 9, 2009, p. 231-239, there is no information about Basilakes), but Nikephoros Basilakes does not appear, see M. GRÜNBART, 'Tis love that has warm'd us. Reconstructing Networks in $12^{\text {th }}$ Century Byzantium, RBPH 83, 2, 2005, p. 301-313.

${ }^{42}$ Circa 1140: first senior positions in a rhetorical school, 26 January 1156: session of the first synod on the issue of orthodoxy.

${ }^{43}$ Such as Robert BRownING in an otherwise inspiring text Enlightenment and Repression in Byzantium in the Eleventh and Twelfth Centuries, PP 69, 1975, p. 18: Much admired by the young, Basilakes was a rhetorician of influence in the literary world. 
Greater precision would require direct data that are lacking ${ }^{44}$, unlike, for example, the rather emotional confessions of Michael Choniates (1138-ca. 1222), their authenticity notwithstanding ${ }^{45}$. Perhaps, as some researchers who have taken an interest in Basilakes have suggested, his character traits were not conducive to social life ${ }^{46}$. In our opinion, the dilemma of the choice between the life of a real

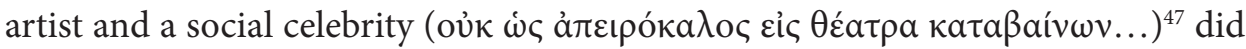
not originally exist, but is rather a rhetorical justification of the failed life of a bitter man. This is a slightly different interpretation from the one Aglae Pizzone proposes, which remains the only comprehensive analysis of the Prologue ${ }^{48}$. We believe that it was in fact the theme of Eros that really formed the discussion - hidden from us - between Basilakes and the romance poets, who belonged to the cultural elite of the empire, "the upper-class intelligentsia"49.

Of course, some of the works of Basilakes feature a more traditional approach. In an ethopoeia that is an ekphrasis of the garden tended by an incompetent gardener ${ }^{50}$. Beauty of the apple tree is there expressed by ekphrasis of Eroses playing

\footnotetext{
${ }^{44}$ E.g. E. JefreeYs, The Sebastokratorissa Irene as Patron, WJK 60, 2012, p. 177-194: meticulous collection of information on the figures related to the foundational activity of Irena - Basilakes was not mentioned; also M. GrünBART, 'Tis love..., passim.

${ }^{45}$ E.C. Bourbounakis, The End of $\dot{\varepsilon} \pi i \delta \varepsilon l \xi ı$. Authorial Identity and Authoria Intention in Michael

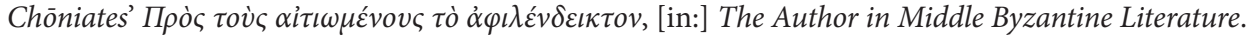
Modes, Functions, and Identities, ed. A. Pizzone, Boston-Berlin 2014 [= BArchiv, 28], p. 201-224.

${ }^{46}$ E.C. Bourbounakis, The End of $\dot{\varepsilon} \pi i \delta \varepsilon l \xi \iota \varsigma . ., 214-115$ : "mental illness"; P. Magdalino, The Empire..., p. 336-337: stern critic of his own literary creations; M. ANGOLD, Autobiography and Identity: The Case of the Later Byzantine Empire, Bsl 60, 1999, p. 41-42: a noble retreat so as not to waste time. ${ }^{47}$ Nikephoros, Praef., VIII, 26sqq, ed. Garzya, p. 5.

${ }^{48}$ A researcher from Odense explains Basilakes' withdrawal from public life with his sincere, personal fear of graphomania ( $\pi 0 \lambda v \gamma \rho \alpha \varphi$ i $\alpha$; what is interesting, is that this word, rarely used before, has begun to appear more often from the twelfth century, see e.g. the beginning of Michael Choniates

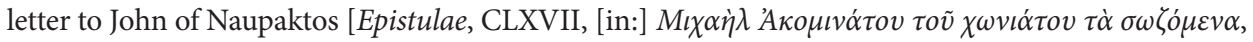
vol. II, ed. S.P. LAmpros, 'A $\theta$ ńva 1880, p. 332], where the author rhetorically stipulates that he will

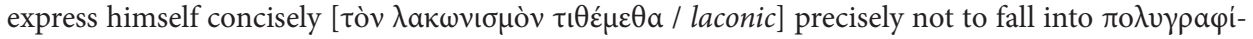
$a v)$ and in consequence of compromising the artistic and ethical standard of his work. We should not forget that Prologue was written after the synods that broke Nikephoros' career, see A. Pizzone, Anonymity, Dispossession and Reappropriation in the Prolog of Nikephoros Basilakes, [in:] The Author in Middle..., p. 225-243. There is no reason to dispute this well-argued line of reasoning. However, there was no follow-up as to why the exaggeration of reading was expressed by the words: $\alpha$ a $\pi \lambda \eta$ $\sigma \tau o \varsigma$ है $\rho \omega \varsigma$ (no attempt was made to track down this semantics in Basilakes' work). Here we can see internal tension, emotions that go beyond the - possibly too calculated - "program caution", and which can be the result of both the contemporary intellectual debate and personal experiences (it is important not only how much we read, but above all, what). From this perspective, this article can be seen as a complement to Pizzone's study.

${ }^{49}$ A.R. Littlewood, An 'Ikon of the Soul': the Byzantine Letter, VL 10, 1976, p. 197.

${ }^{50}$ Niceforo Basilace, Progymnasma, LV, ed. Pignani, p. 225-228, 364-366; Nikephoros BasiLAKes, Ethopoeia, XXVI, ed. BeneKer - Gibson, p. 314-321.
} 
with fruits of the tree ${ }^{51}$. The use of plural is not metaphorical or informative (there is only one Eros, after all), but modal - it is intensitivum meant to emphasize the power of god's presence ${ }^{52}$. It is expressed in the visual beauty of the fruit and its primeval erotic symbolism, which survived until Byzantine times ${ }^{53}$. This is evidenced, among other things, by the popularity of the story of Emperor Theodosius giving his wife Eudocia an apple, which then returned to him via Paulinus, the empress' friend... ${ }^{54}$ In the monophysite version, the emperor gives it to his sister Pulcheria, who in turn gives it to her lover Marcian ${ }^{55}$. But also in his use of pluralis does Basilakes challenge convention, when the description of the "villainous character" of the aforementioned Goth, apart from egoism and uncouth

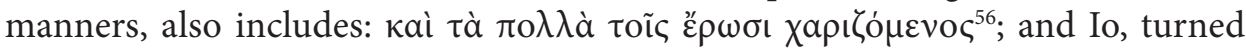

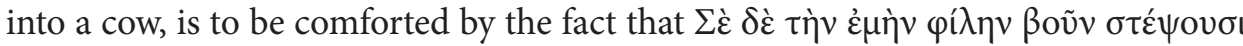
$\mu \grave{\varepsilon} v^{\prime E} E \omega \tau \varepsilon \varsigma . .{ }^{57}$ It is an image of dark irony, but essentially identical to the depiction of Erotes circulating during a dream wedding ${ }^{58}$.

\section{Eros in the Romance of the age of the Komnenoi}

Pierre-Daniel Huet (1630-1721) was the author of a short work Traité de P'Origine des Romans, now somewhat forgotten but nevertheless highly interesting from the point of view of the history of Byzantine literature. It was published as an introduction to the edition of the novel Zaïde by Madame de La Fayette (Marie-Madeleine Pioche de la Vergne, comtesse de La Fayette, 1634-1693), the first volume

\footnotetext{
${ }^{51}$ Niceforo Basilace, Progymnasma, LV, 16-17, ed. Pignani, p. 225; Nikephoros Basilakes, Ethopoiea, XXVI, 1, ed. Beneker - Gibson, p. 314-315; cf. Niceforo Basilace, Progymnasma, LI, 13-14, ed. Pignani, p. 208; Nikephoros Basilakes, Ethopoeia, XXII, 2, ed. Beneker - Gibson, p. $280-281$.

${ }^{52}$ Cf. Plato, Philebus, 50d, [in:] Platonis opera, vol. II, rec. J. Burnet, Oxonii 1967; Plutarchus, Philopoimen, XVII, 1, [in:] Plutarchi vitae parallelae, vol. II.2, rec. K. ZIEGLER, Lipsiae 1968, p. 21. ${ }_{53}$ A.R. Littlewood, The Symbolism of the Apple in Byzantine Literature, JÖB 23, 1974, p. 33-59. Cf. I. Nilsson, E. Nyström, To Compose, Read, and Use a Byzantine Text: Aspects of the Chronicle of Constantine Manasses, BMGS 33, 2009, p. 49-51.

${ }^{54}$ A.D.E. Cameron, The Empress and the Poet: Paganism and the Politics at the Court of Theodosius II, YCS 27, 1982, p. 217-289; R. Sсотт, From Propaganda to History to Literature: The Byzantine Stories of Theodosios' Apple and Marcian's Eagles, [in:] Byzantine History as Literature, ed. R. MACRIDES, London 2010, p. 115-133.

${ }^{55}$ R. Burgess, The Accession of Marcian in the Light of Chalcedonia Apologetic and Monophysite Polemic, BZ 86/87, 1993/1994, p. 47-68; M. von EsBroeck, La pomme de Théodose II et sa réplique arménienne, [in:] Novum Millenium. Studies on Byzantine History and Culture Dedicated to Paul Speck, ed. C. Sode, S. TaKács, Aldershot 2001, p. 109-111.

${ }^{56}$ Niceforo Basilace, Progymnasma, LVI, 14, ed. Pignani, p. 229; Nikephoros Basilakes, Ethopoeia, XXVII, 1, ed. BENEKER - GIBSON, p. 322-323: given over almost entirely to sexual desires.

${ }^{57}$ Niceforo Basilace, Progymnasma, XlVII, 73, ed. Pignani, p. 196; Nikephoros Basilakes, Ethopoeia, XVIII, 6, ed. BeNEKER - GiBson, p. 256-257: You, my dear cow, the Erotes will crown.

${ }^{58} \mathrm{HH}$ 5, 2 (abbreviation see below).
} 
of which was published in 1669. The text of the Treatise, printed in 1670-1671, was soon translated into English and published separately in $1672^{59}$. Having rightly recognized the innovative character of Madame de La Fayette's novel ${ }^{60}$, Huet decided to add an outline of the history of the genre. Of course, the vast majority of information contained therein is already outdated, but its historical significance consisted in including works from the Byzantine culture into the synthetic history of the genre. Huet believed that in order to be called a romance, a literary piece had to meet two basic criteria, which in their essence have not changed to this day: a) "lamour de l'homme"61 and b) "lesprit fabuleux" 62 . In the $12^{\text {th }}$ century, four pieces were written that met these requirements: Rodanthe and Dosikles (hereinafter: RD, ca. 1140) by Theodore Prodromos, Drosilla and Charikles (hereinafter: DCh,

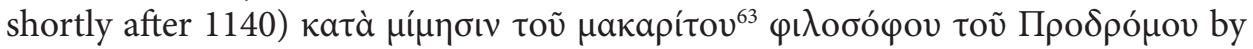
Niketas Eugenianos ${ }^{64}$, Hysimine and Hysimines (hereinafter: HH, mid-1140s) by Eumathios Makrembolites (1150s?) ${ }^{65}$ and Arístandros and Kallithéa by Constantine Manasses (not included in the analysis, see above) ${ }^{66}$.

\footnotetext{
${ }^{59}$ Lettre-traité de Pierre-Daniel Huet sur lorigine des romans, éd. F. GÉGOU, Paris 2005; the author of this article used the 1671 editio, p. 5-67.

${ }^{60}$ The first modern psychological novel, in addition written by a woman. What turned out to be an even bigger bestseller was La Princesse de Clèves, 1678.

${ }^{61}$ Cf. P. RoIlos, Amphoteroglossia. A Poetics of the Twelfth-Century Medieval Greek Novel, Cambridge 2005, passim, in particular p. 32-40.

${ }^{62}$ Note that in classical terminology it can be defined the aforementioned diegesis, diegema, narratio. ${ }^{63}$ Of blessed memory, i.e. dead, particularly, what is important here, the one that has died recently. ${ }^{64}$ A. Kazhdan, Bemerkungen zu Niketas Eugenianos, JÖBG 16, 1967, p. 101-117; F. Conca, Il romanzo di Niceta Eugeniano: Modelli narrativi e stilistici, SG 39, 1986, p. 115-126; C. Jouanno, Nicétas Eugénianos, un héritier du roman grec, REG 102, 1989, p. 346-360.

${ }^{65}$ Another author disagrees, С.В. ПоляковА, О хронологической последовательности романов Евматия Макремволита и Феодора Продрома, ВВ 32, 1971, p. 104-108; ЕАDЕм, К вопросу о датировке романа Евматия Макремволита, ВВ 30, 1969, p. 113-123 (the author collected loci similes of Basilakes and Makrembolites which were later used by Adriana Pignani in her edition; e.g. the extremely detailed, three-page list of similia deserves a separate article and verification due to the extraordinary abundance of themes and symbols, many of which have their own history), moving Macrembolites to the turn of the $11^{\text {th }}$ and $12^{\text {th }}$ centuries and considering it to be a work that marked the start of renewal (also for the West as an inspiration for Roman de la Rose). For a long time, most of the studies ignored her suggestions and it was only Suzanne MACAlister who resumed the interpretation of the Soviet scholar in the article Byzantine Twelfth-century Romances: a Relative Chrono$\log y$, BMGS 15, 1991, p. 175-211. However, their arguments, which are based on the establishment of the direction of the borrowing of certain themes, cannot be considered conclusive, in particular in view of the statements made by Carolina Cupane, Metamorphosen des Eros. Liebesdarstellung und Liebesdiskurs in der byzantinischen Literatur der Komnenezeit, [in:] Der Roman im Byzanz der Komnenenzeit, ed. P.A. Agapitos, D.R. Reinsch, Frankfurt am Main 2000 [= Mel, 8], p. 52-54: reading

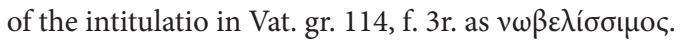

${ }^{66}$ Ingela NiLsson has written a number of treatises from a genological point of view, including the monograph Erotic Pathos, Rhetorical Pleasure: Narrative Technique and Mimesis in Eumathios Makrembolites" "Hysmine \& Hysminias", Uppsala 2001 [= SBU, 7]; A. Cataldi PalaU, La tradition
} 
As a narrative frame, the "illusion of antiquity" ${ }^{\text {, }}$, apart from the reference to the convention of the genre, serves primarily to strengthen the universal dimension of the moral standard, liberating it from the limitations of a particular religion, or even from its distorted, overly zealous forms ${ }^{68}$. For both the heroes and their enemies, love appears at first sight upon encountering unexpected beauty that captivates and enchants them ${ }^{69}$. Hence, the ekphrasis ${ }^{70}$ of Rhodante appears as early as the beginning of $\mathrm{RD}^{71}$. Gobryas, the pirate chief of arms, was stunned by the sight of the girl that he had kidnapped together with other residents of Rhodes. Prodromos skillfully uses the contrast between the girl's gentleness and the brutal roughness of the pirate ${ }^{72}$ :

manuscrite d'Eustathe Makrembolitès, RHT 10, 1980, p. 75-113. Also noteworthy is P. RoILos, Amphoteroglossia... with various detailed remarks. Italian translation: Il Romanzo Bizantino del XII secolo, ed. F. ConCA, Torino 1994 [= CG.ATAB]; English: Four Byzantine Novels, trans. E. JefFreys, Liverpool 2012 [= TTB, 1]; Niketas Eugenianos, Drosilla and Charikles. A Byzantine Novel, trans. et ed. J.B. Burton, Wauconda 2004 (Greek text after the Italian edition); critical editions: Theodori Prodromi De Rhodanthes et Dosiclis Amoribus Libri IX, ed. M. MArCovich, Stutgardiae-Lipsiae 1992 [= BSGR]; Eustathius Macrembolites, De Hysmines et Hysminiae Amoribus Libri XI, ed. M. Marcovich, München-Leipzig 2001. Unfortunately, it should be emphasized that this edition's author is ignoring Herbert Hugner's unmistakable findings (following K. HorNA, Die Epigramme des Theodoros Balsamon, WSt 25, 1903, p. 182-183, 206-209) regarding the form of the name: Eumathios instead of Eustathios: H. Hunger, Die Makremboliten auf byzantinischen Bleisiegeln und in sonstigen Belegen, SBS 5, 1998, p. 4-8.

${ }^{67}$ A. Kaldellis, Hellenism in Byzantium. The Transformations of Greek Identity and the Reception of the Classical Tradition, Cambridge 2007, p. 258-259.

${ }^{68}$ The extreme views that existed in Byzantine society at the time are evidenced by the writings of Neophytos of Cyprus, see C. Galatariotou, Eros and Thanatos: A Byzantine Hermit's Conception of Sexuality, BMGS 13, 1989, p. 95-137. In the world of Neophytos (d. 1214) there was no room for the main figures of this article.

${ }^{69}$ Also in Nicephoros' progymnasmata physical tò ká $\lambda \lambda$ oc is a cause of a nascent feeling.

${ }^{70}$ J. ELSNER, Introduction: The Genres of Ekphrasis, Ram 31, 2002, p. 1: Ekphrasis is a descriptive speech which brings the thing shown vividly before the eyes. This definition, with minor changes, appears in Greek tradition from Theon to Nikolaos. Cf. H. Maguire, Truth and Convention in Byzantine Descriptions of Works of Art, DOP 28, 1974, p. 111-114; R. Wевв, Ekphraseis of Buildings in Byzantium: Theory and Practices, Bsl 69, 2011, p. 20-32 (see also her previous works); R. MACRIDES, P. Magdalino, The Architecture of Ekphrasis: Construction and Context of Paul the Silentiary's Poem on Hagia Sophia, BMGS 12, 1988, p. 47-82; E.M. van Opstall, On the Threshold. Paul the Silentiary's Ekphrasis of Hagia Sophia, [in:] Sacred Thresholds. The Door to the Sanctuary in Late Antiquity, ed. IDEM, Leiden-Boston 2018 [= RGRW, 185], p. 31-65 (but from the perspective of religious studies); V. Foskolou, Decoding Byzantine ekphraseis on Works of Art. Constantine Manasses's Description of Earth and Its Audience, BZ 111, 2018, p. 71-102, which discusses the problem of an ability of reconstructing a work of art, based on literary ekphrasis, which must include "readership's horizon of expectations". For understandable reasons, none of the categories of ekphrasis is as popular as those on works of art (we may even ask, whether the ekphrasis of works of art were a separate subgenre), so we do not have studies as thorough as the above model examples, which would concern e.g. ekphraseis of emotions.

${ }^{71} \mathrm{RD} 1,39-60$.

${ }^{72} \mathrm{RD} 1,68-70$, trans. E. Jeffreys. 


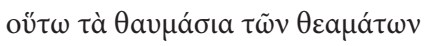

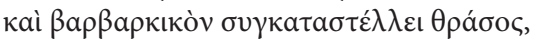

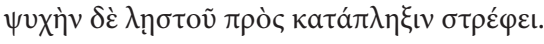

To such an extent did the wondrous spectacle

cast down even the barbarian's temerity,

and bring confusion to the robber's soul.

A similar pattern of enchantment is later found in the case of Kratander, Dosikles' companion in a dungeon ${ }^{73}$, or the hero himself ${ }^{74}$. When Dosikles unsuccessfully tries to fall asleep after a conversation with Kratander, he talks to himself about how the beauty of Rhodante made him feel ${ }^{75}$. In all of this the lack of a god of love is striking, both at the level of the plot and the metaphor. It is only in the last verses of the second book that Dosikles, concluding his retrospection of the kidnapping of his beloved, praises Eros for his power ${ }^{76}$, but one cannot help feeling that it is only a scholastic formality. Here we find all the topoi: Eros is deceptively charming, older than Kronos in spite of having the body of a child ${ }^{77}$; he rages with a smile on his face; he blows fiery missiles in the hearts of others; no creature can resist him. At this point, Prodromos' narrative takes a surprising turn, as companions reprimand Dosikles, unable to bear the artificiality of his exalted speech ${ }^{78}$ :

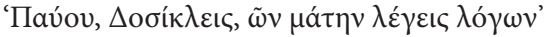

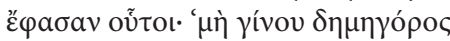
(åm

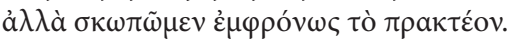
'Stop your pointless speech, Dosikles,'
they said, 'Don't be an orator
(for philosophizing is inappropriate now),
but let us consider sensibly what has to be done.

Is it the case that Prodromos uses the narrative frame to safely smuggle an allusion to some political-ideological struggles, as Suzanne MacAlister claims, linking these words to the condemnation of Eustratius of Nicaea $(1117)^{79}$ ? In fact, there

\footnotetext{
${ }^{73} \mathrm{RD} 1,164-169$.

${ }^{74} \mathrm{RD} 2,188-220$.

${ }^{75} \mathrm{RD} 2,210-211$.

${ }^{76} \mathrm{RD} 2,421-431$.
}

${ }^{77}$ S. MACAlister, Byzantine Twelfth-century Romances..., p. 206: suggests that RD 2, 422 is the reply to $\mathrm{HH} \mathrm{2,} \mathrm{9,} \mathrm{hence} \mathrm{it} \mathrm{is} \mathrm{important} \mathrm{to} \mathrm{shift} \mathrm{the} \mathrm{chronology} \mathrm{of} \mathrm{the} \mathrm{romances;} \mathrm{however,} \mathrm{the} \mathrm{direction}$ of the relationship is not clear and the ambiguous nature of god had not been a secret for anyone for a long time, cf. Plato, Symposium, 178c, [in:] Platonis opera....

${ }^{78} \mathrm{RD} 2,432-435$, trans. E. Jeffreys.

${ }^{79}$ S. MACAlister, Byzantine Twelfth-century Romances..., p. 206-207. 
is no slightest evidence of this. It seems that this is rather one of those interesting formal solutions for which Theodor was famous. The phrase $\varphi \iota \lambda$ oбopia, used here in the pejorative sense 'to pretend to be wise, to confabulate, to exaggerate', appears only once in the entire work (both of these facts alone exclude the hypothesis involving Eustratius, whose possible defense would be much better prepared and based on emphasizing its orthodoxy, and not on increasing the effect of uniqueness). This reinforces the impression of a switch to a lower register, which serves to highlight the here's naivety in the throes of his first love.

Later, Prodromos emphasizes two negative examples of actions by Eros, who often leads people to self-destruction: the already mentioned pirate Gobryas, who pierced himself with his own sword ${ }^{80}$, and an unknown woman from Rhodes. The latter, hit by two arrows of the god (adequately described in this context as

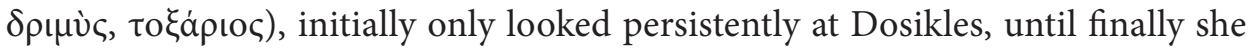
ran up to him and partially tore off his robe ${ }^{81}$. This episode was unusually drastic from the perspective of the time. It should be remembered that all initiatives and reflections on Eros' nature come from a man. With her act, the girl violated all the standards, including aretai, mentioned earlier in the Aristotelian definition. The worst thing is that her humiliation was nothing but a game for the $\operatorname{god}^{82}$ :

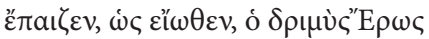

fierce Eros had his sport, as is his custom

All these romances, despite their many differences, agree that the couple in love are innocent ${ }^{83}$ when the feeling develops and that they maintain the highest moral standards (not just in the sexual sphere) in spite of many misfortunes and psychologically difficult situations they face. Certainly, this situation leads to psychological contradictions ${ }^{84}$. The above argument demonstrates how important for

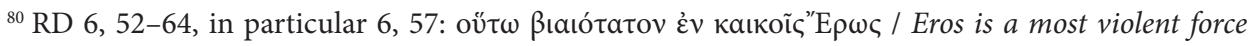
in men of evil disposition, trans. E. Jeffreys.

${ }^{81} \mathrm{RD} 8,191-209$.

${ }^{82} \mathrm{RD} 8,192$, trans. E. Jeffreys. However, the word 'sport' seems inappropriate at this point and it should rather be "he was playing".

${ }^{83}$ Confusing innocence with 'passivity', which in addition has an extremely pejorative sense in contemporary view: from simple ineptitude to passive submission of life, it is a grave misinterpretation committed by C. Christoforatou, The Iconography of Eros and the Politics of Desire in Komnenian Byzantium, E.PMAM 12, 2005, p. 72; in the remaining parts of the article, the author follows Paul Magdalino's interpretation of Eros as an element of imperial ideology (see below).

${ }^{84}$ C. Jounnno, Les Jeunes filles dans le roman byzantin du XII e siècle, [in:] Les Personnages du roman grec. Actes du colloque de Tours, 18-20 novembre 1999, ed. B. Pouderon, C. Hunzinger, D. KASPRZYK, Lyon 2001, p. 341: “indéniable tension". Cf. a broad study of sexual morality, showing the nuance present in various literary trends, not only in romance (despite the title): L. GARLAND,
} 
the understanding of the meaning of Eros in Theodore Prodromos' romance are the words of Rhodante spoken to a kind old woman named Myryllis, who gave her shelter, where Dosikles ultimately found her ${ }^{85}$ :

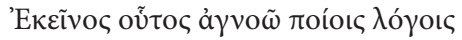

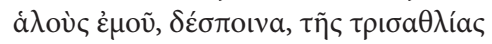

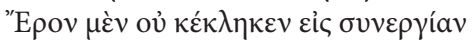

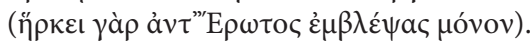 \\ That young man for reasons of which I am ignorant \\ was smitten by me, the thrice wretched; \\ it was not Eros whom he summoned as his accomplice \\ (for his mere appearance was a sufficient substitute for Eros).
}

God is therefore not so much the source of evil love, for such does not exist ${ }^{86}$, as an unhappy one, such as the feeling that affected the aforementioned Kratander ${ }^{87}$. Any involvement of the deity frees us from the responsibility for our deeds, sometimes not particularly worthy of remembering, which we commit under its influence. Rhodante, therefore, rejects Eros and paradoxically saves the genuineness and future happiness of her own love.

The romance by Niketas Eugeneianos is completely devoid of such ambiguity. Eros tyrannos manifests himself in all his power, controlling the fate of people as he sees fit. We get to know the protagonists in medias res according to the standard of ancient romance. Kratylos, Parthian ruler, plunders the city of Barzon, and Drosilla and Charikles are among the prisoners he takes ${ }^{88}$. They had met and fell in love earlier, at the feast of Dionysus. During their sea voyage to Drosilla's family they unfortunately came across pirates. The storm allowed them to slip out, but they made the unfortunate decision to stay in Barzon for a while. According to the rules of the genre, their new owners, King Kratylos and Queen Chrysilla, fall in love with them, though their feelings are not reciprocated. The latter even poisons her husband to remove an obstacle to her relationship with Charikles, but soon commits suicide after losing the battle with the Arabs ${ }^{89}$. In her last message to the young couple she stresses that her feelings are the responsibility of ä $\varphi v \kappa \tau о \varsigma^{\prime \prime} \mathrm{E} \rho \omega \varsigma^{90}$,

\footnotetext{
'Be Amorous, But Be Chaste...': Sexual Morality in Byzantine Learned and Vernacular Romance, BMGS 14, 1990, p. 62-120; A. LAIou, The Role of Women in Byzantine Society, JÖB 31, 1981, p. 233-260.

${ }^{85}$ RD 7, 239-242, trans. E. Jeffreys.

${ }^{86}$ Cf. Basilakes' defense of Pasiphaë, described above.

${ }^{87} \mathrm{RD} 1,190-205$.

${ }^{88}$ DCh $1,1-74$.

${ }^{89}$ DCh 5, 434-438.

${ }^{90}$ DCh 5, 199: “inescapable love” trans. J.B. Burton; E. Jeffreys.
} 
"E $\rho \omega \varsigma \delta \grave{\varepsilon} \tau \cup \varphi \lambda{ }^{\prime} \varsigma^{91}$, i.e. one that cannot be rationalized. Interestingly, nobody disputes the truthfulness of these words. Unlike in any other romance, Niketas' Eros is a deterministic, pessimistic power $(\pi \dot{\theta} \theta \text { oc) })^{92}$ :

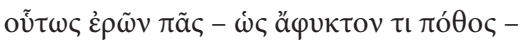

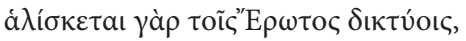

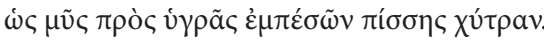

Thus every lover (how inescapable love is!)

is caught by the nets of Eros,

just like a mouse who's fallen into a pot of pitch ${ }^{93}$.

Thus everyone who is in love - and what an ineluctable thing is passion -

is entrapped in eros' snares,

like a mouse that has fallen into a pot of sticky resin ${ }^{94}$.

The luckless Kleandros (the equivalent of Kratander in $\mathrm{RD}$ ) uses surprisingly brutal language in his correspondence with Kalligone, to which he never received an answer ${ }^{95}$ :

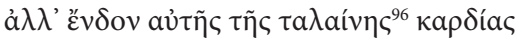

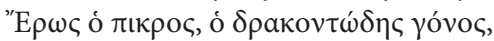

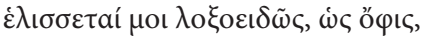

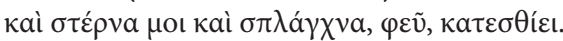

but within my wretched heart,

cruel Eros, the snake-child,

rolls around obliquely, like a serpent,

and devours my heart and inward parts, alas ${ }^{97}$

${ }^{91}$ DCh 5, 217: "Eros is blind" trans. J.B. Burton; E. Jeffreys.

${ }^{92}$ DCh 4, 408-410.

${ }_{93}$ Trans. J.B. Burton.

${ }^{94}$ Trans. E. Jeffreys.

${ }^{95}$ DCh 2, 216-219. Another aspects of Kleandros' misfortune, including his death and funeral, see detailed analysis in J.B. Burton, A Reemergence of Theocritean Poetry in the Byzantine Novel, CP 98, 2003 , p. $262-267$.

${ }^{96}$ This is one emotionally strong ephitet, indicating a terrible emotional suffering; it is quite often used by Euripides, he uses tádaıva to describe Medea (e.g. Med. 277, 996), Alcestis (Alc. 250), Hecuba (Hec. 514), Euripidis fabulae, vol. I, Cyclops, Alcestis, Medea, Hereclidae, Hippolytus, Andromacha, Hecuba, ed. J. Diggle, Oxford 1984 [= SCBO]. In Sophocles, it is Tecmessa (Ajax 340-341) unsucccesfully trying to stop Ajax for commiting suicide; Electra (El. 304, 388), Eurydice (Ant. 1180), Sophoclis fabulae, rec. H. LLOYD-Jones, N.G. WiLson, Oxonii 1990 [= SCBO].

${ }_{97}$ Trans. J.B. Burton. 
But within my unhappy heart itself bitter eros, that serpentine offspring, insinuates himself into me obliquely, like a snake, and - alas - devours my breast and my entrails ${ }^{98}$.

Finally, Queen Chrysilla tries to explain the murder by forces that are more powerful than her. However, it is not the whim of the child god, as in Prodromos' work, but the non-personal power of nature, of which Eros is only a pale personification ${ }^{99}$. Using contemporary language, it is an omnipresent life energy, amoral in the sense of lack of immanent ethical valuation.

The perspective of Eumathios Macrembolites is surprisingly different and at the same time the most mature of all three takes on the theme. HH is distinguished by its radical shift of emphasis from the plot to the allegoresis, to an extent unprecedented in the other romances. The first five of its eleven books are, to a large degree, ekphraseis, interrupted by a barely feigned dialogue: ekphraseis of works of art, of people, of feelings that "concentrate on emotion and fantasy"100. All of them have one goal: to show Eros' power in all its ambiguity as a guarantor of the cosmic order (yes, I am aware that from the Greek perspective it is merely a tautology!). There is a fundamental difference between this vision and Niketas' vitality: the Eros of Makrembolites is transcendent, while that of the other author is immanent to the world. In such circumstances people have two ways of touching the god, both fully established in tradition - namely dream ${ }^{101}$ and art. They ensure the authenticity of the relationship and, at the same time, save us from the literalness in which Niketas was so immersed and which Prodromos did not trust. It is therefore only natural that when Hysminias first confesses to his friend Kratisthenes ${ }^{102}$ :

${ }^{98}$ Trans. E. Jeffreys.

${ }^{99}$ DCh 5, 218-220.

${ }^{100}$ M. Alexiou, A Critical Reappraisal of Eustathios Makrembolites' Hysmine and Hysminias, BMGS 3, 1977, p. 29.

${ }^{101}$ Dream is a state in which a person can learn the truth without any falsification or mental limitations brought by the real world; paradoxically, therefore, what is incomprehensible consciously becomes realized in a subconscious dream: N. Kalogeras, Education Envisioned or The Miracle of Learning in Byzantium, Bsl 64, 2006, p. 111-124 (= ZAC 13, 2009, p. 513-525). Cf. G. Calofonos, Dream Interpretation: A Byzantinist Superstition?, BMGS 9, 1984-1985, p. 215-220; P. Cox MiLLER, Dreams in Late Antiquity. Studies in the Imagination of a Culture, Princeton 1998. In both these works the reader will find bibliographic references to oneirocritical literature, but see also a new important publication: Dreambooks in Byzantium. Six Oneirocritica, trans. et comm. S.M. OBerheLMAN, Aldershot-Burlington 2008. This interpretation of Hysminias' dream is different from the one proposed by M. Alexiou (A Critical Reappraisal...), who - somewhat anachronistically - sees the dreams as the protagonist's own subconscious and not a gateway to another world. Suzanne MACAlister (Aristotle on the Dream: A Twelfth-Century Romance Revival, B 60, 1990, p. 195-212) analyzes dreams present in romance as a subject of debate at theatron, which had to combine the traditions of Antiquity, contemporary sensitivity and subtle naturalistic elements ("wet dreams").

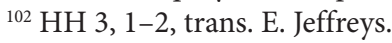




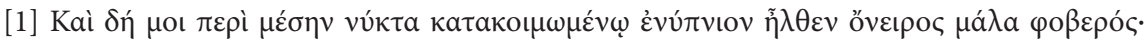

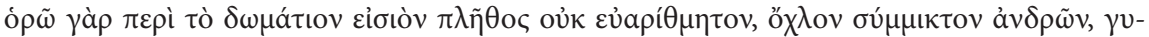

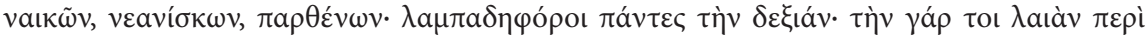

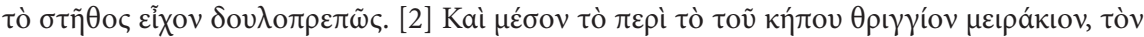

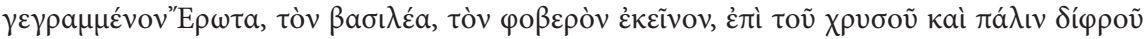

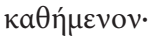

[1] And then about the middle of the night, while I was sleeping, a vision came to me, a rather terrifying dream; for I see a crowd of inestimable size entering the chamber, a mixed throng of men, women, youths, maidens. All held torches in their right hands while their left they placed on their breasts in a servile manner. [2] And in the middle was the lad who was painted on the wall around the garden, Eros, the emperor, that terrifying figure, seated on his golden throne once more.

And after a brief presentation of the situation, the god accepted his love for Hysmine $^{103}$ :

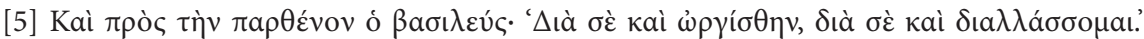

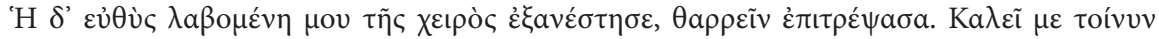

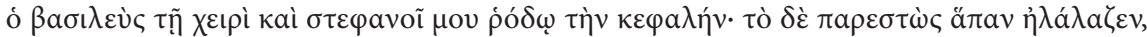

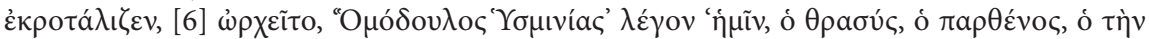

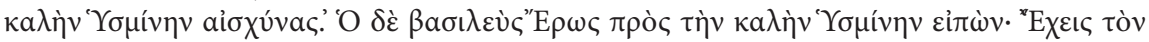

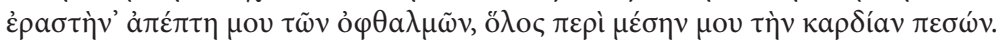

[5] And the emperor said to the maiden, "It is for your sake that I was angry, so for your sake I receive him back in favour". She immediately took my hand and made me stand up, telling me to be confident. The emperor summons me with a gesture and crowns my head with roses. All the bystanders cried out and applauded, [6] and danced around, saying, "Hysminias has become our fellow slave, the bold, the unwed, who spurned the lovely Hysmine". Then saying to the lovely Hysmine, "You have your lover," the emperor Eros flew away from my eyes and plunged deep into my heart.

Paradoxically, despite the ubiquitous ekphrasis, physicality goes to the background in Makrembolites' work. The concrete quickly loses its realism because it is subject to a sublime metaphorical interpretation. What really is true, Eumathios seems to say, happens in our hearts and minds. Feelings are the only thing that is authentic, and this is partly expressed by the figure of Eros basileus. Let us remember this change of epithet: the more popular tyrannos had to give way ${ }^{104}$. It cultivates love as an inner motion of the human heart, not an external whim or impulse. It is no coincidence that Hysminias is the first hero of the Greek romance to experience all his love in a dream. Its equivalent in this world is the garden of Sosthenes, whose long ekphrasis is absolutely vital for the understanding of the whole work. Hysminias walks around the garden with his friend Kratisthenes,

${ }^{103} \mathrm{HH} 3,5-6$, trans. E. Jeffreys.

${ }^{104}$ DCh $4,412$. 
admiring it and describing with such sensitivity and metaphor that the reader starts to realize that the Garden, which can now be spelled with a capital letter, is but an allegory of the universe ${ }^{105}$. Its key element is an image dominated by the four forms of aretai: Phronesis, Ischys, Sophrosyne and Themis. The ladies are easy to identify because above each one's head there is a part of a single-verse iambic inscription. The whole depiction is described as a $\delta \rho \tilde{a} \mu \alpha$ (action, performance) $)^{106}$ and Hysminias' summary of the description indicates the need for allegorical

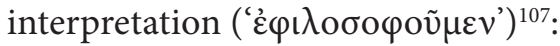

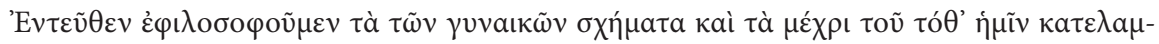

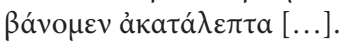

Then we discussed the women's appearance and we comprehended what till then had been incomprehensible to us $[\ldots]$.

The manner in which Eros is depicted is ambiguous, if not disturbing ${ }^{108}$. He is painted as a naked boy with winged feet, sitting on a throne worthy of a "Mycenaean tyrant", holding a bow and fire in his hand. He is surrounded by a crowd of men and women of all ages and of different skin colors, in a position indicating submissiveness ${ }^{109}$. And there are twelve scenes depicting activities specific to a given season ${ }^{110}$. Hysminias understands that the image carries a hidden message ${ }^{111}$ :

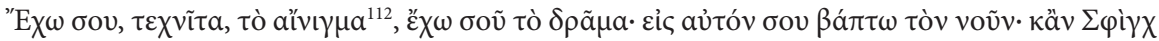

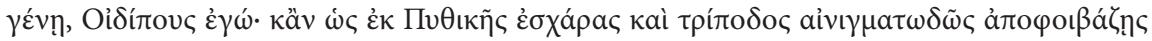

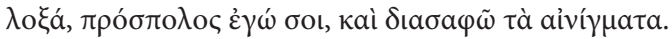

${ }^{105}$ Reference material, cf. C. Cupane, Orte der Liebe: Bäder, Brunnen und Pavillons zwischen Fiktion und Realität, Bsl 69, 2011, p. 167-178; A.R. Littlewood, Romantic Paradises: The Role of the Garden in the Byzantine Romance, BMGS 5, 1979, p. 95-114.

${ }^{106} \mathrm{HH} 2,6,1$.

${ }^{107} \mathrm{HH} 2,6,2$, trans. E. Jeffreys.

${ }^{108} \mathrm{HH} 2,7$.

${ }^{109} \mathrm{HH} 2,9 ; 4,4$.

${ }^{110}$ HH. 4, 4-18, see E. Jefreneys, The Labours of the Twelve Months in Twelfth-century Byzantium, [in:] Personification in the Greek World. From Antiquity to Byzantium, ed. E. Stafford, J. Herrin, Aldershot 2005, p. 309-324; P. RoILos, Amphoteroglossia..., p. 161-168. An extremely mysterious motif: it is an astronomical symbolism of the whole year, thus indicating the holistic aspect of time (aiōn, and not the divisible chronos [dated according to various human, culturally determined systems]), in which everything has its own time, its own season (hence the kairos), but at the same time the measurable passage of time (chronos) is unimportant. Placing this image in the context of Eros points to god's power over time. The garden, on the other hand, is a cosmos as an external reality but also an internal reality as a psyche of Hysminias. On both levels there is a constant and inevitable conflict between Aretai and Eros, who is inside and outside, in time and beyond it. He is simply a God.

${ }^{111} \mathrm{HH} 2,8,2$, trans. E. Jeffreys.

${ }^{112}$ A term that surprisingly rarely appears in the context of this myth (TLG: access on May 5, 2018), so it seems that its presence here may have attracted the attention of the recipient/auditor. The 
I can grasp, craftsman, your riddle, I can grasp what you have done ( $\delta \rho \tilde{a} \mu \alpha)$, I can immerse my mind in yours ${ }^{113}$; even if you are Sphinx, I am Oidipous; even if you utter riddling prophecies from the Pythia's hearth and tripod, I am your priestly attendant and I can interpret your riddles.

The ambivalence of Apollo's oracle is intended to show an interpretation of a work of art as a mystical experience. In this particular case, Hysminias needs to understand what love is. Although Kratisthenes tells him that this is the force that brought the universe into existence and still sustains all living beings, Hysminias must experience it himself. This, I think, is the torch in Eros' hand - an invitation to the mystery ${ }^{114}$.

It might be worth mentioning here a similar scene from the ancient romance by Achilles Tatios, entitled Leucippe and Clitophon, well-known, read and appreciated in Byzantium ${ }^{115}$. While visiting a temple of Astarte in Sydon, the narrator admires a painting depicting the abduction of Europe. His attention is focused on admiring the power of the god and the literal eroticism emanating from the image. Makrembolites, who knew the text very well, borrowed the setting but gave it a completely different meaning. The Byzantines saw the process of personification as a type of metaphor, within the broader framework of the problem of real-

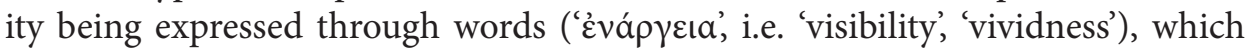

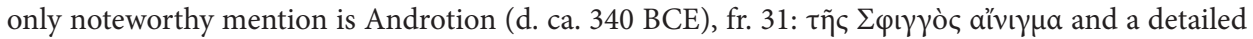
account of its content. However, the above opinion will remain only a hypothesis because we must remember that only a small fragment of Ancient and Byzantine literature has arrived to our times and we will never be able to make unanimous judgements regarding lexical statistics.

${ }^{113}$ Cf. Niceforo Basilace, Monodia, I, 186, ed. Pignani, p. 243: عiৎ voũv ßá $\tau \tau \omega v$, p. 377: [...] l'intingevi nella mente. The mutual references in this passage confirm and at the same time go beyond Kaldellis' statement, Hellenism in Byzantium..., p. 260: There are, in fact, close textual and generic links between Basilakes' progymnasmata and the novel of Makrembolites; both, after all, were products of the same Hellenizing milieu and its rhetorical background.

114 There is a fascinating discussion on the genesis of this image in particular, and Eros in romance in general. Paul Magdalino (Eros the King and the King of "Amours": Some Observations on "Hysmine and Hysminias", DOP 46, 1992, p. 197-204), sees it as a reflection of the symbolism of the imperial age of the Komnenoi; Carolina Cupane, on the other hand, whose dissertations continue to be a model of analysis ('E $\rho \omega \varsigma \beta \alpha \sigma i \lambda \varepsilon v$ ç: La figura di Eros nel romanzo bizantino d'amore, AASLAP 4 ser., 33, 1973-1974, p. 243-297 and Metamorphosen des Eros..., p. 40sqq), prefers a synthesis of Antiquity traditions and Western models, although her perspective may be disturbed by the fact that she also discusses the so-called folk romance of the Paleologists' era (cf. its Italian translation: Romanzi cavallereschi bizantini, ed. C. Cupane, Torino 1995), while Elisabeth Jefrreys sees the opposite direction of inspiration: The Comnenian Background to the Romans d'Antiquité, B 50, 1980, p. 455-486). Undoubtedly, the social realities of the $12^{\text {th }}$ century were favorable to the subject matter, after all, there is no question that the renewal of the romance took place at that time. However, the discussion on Eros has an extremely internal, psychological character, as evidenced by its unprecedented intensity and diversity of view: are the studies on the myth of Pasiphaë presented above not in contradiction with any 'political' arguments?

${ }^{115}$ Cf. Michael Psellus, The Essays on Euripides and George of Pisidia and on Heliodorus and Achilles Tatius, ed. A.R. Dyck, Wien 1986 [= BV, 16]. 
occupied them even more than their ancient predecessors ${ }^{116}$. These emotions can be seen in the way the friends talk about the painting: they treat it as a challenge, a puzzle that conceals a mystery; an embodiment of the truth that not everything can be said, that there are things for which there are no adequate words. How far removed it is from the scene in Sidon, where there is no secret, everything is revealed and comes down to the pleasure of contemplation of an emotionally charged, purely physical beauty.

This above outline highlights the very diverse representations of Eros in romance, too ambiguous to be reduced to rhetorical strategies; in my opinion, it reflects the emotions that had to be present in the $12^{\text {th }}$-century Byzantine society. For reflection on the essence, origin and value of feelings exceeds genological conditions and is almost modern, extremely psychological in nature. This is the thread of Ariadne that binds theatron poets to Basilakes.

\section{Conclusion: Did Basilakes belong to the literary circle of the palace?}

A very interesting relation between Eros and the theatrical terminology is demonstrated by an ethopoeia ${ }^{117}$ entitled What Love would say when he sees a woodcutter attempting to chop down Myrrha while she was still pregnant with Adonis ${ }^{118}$. The god informs man that he should be careful about what he is cutting because some trees and, more broadly, plants are, as we say today, "not from this world", and as such they are inviolable. As examples he cites Narcissus, Daphne and Hyacinth; now he forbids to harm Myrrha, a girl turned into a tree as a punishment for an incestuous relationship with her father. He explains that in fact it was his own doing ${ }^{119}$, summarizing the warning in a lofty manner ${ }^{120}$ :

\footnotetext{
${ }^{116}$ S. GoldHILL, What is Ek kphrasis for?, CP 102, 2007, p. 1-19; esp. p. 3-6 about the impact of the image on the psyche of the viewer.

${ }^{117}$ Niceforo Basilace, Progymnasma, LI, ed. Pignani, p. 207-210, 354-355; Nikephoros BasiLAkes, Ethopoeia, XXII, ed. Beneker - Gibson, p. 280-286. Parisinus gr. 2544 (saec. XVI) as his last work (ff. 125v.13-126v) contains an ethopoeia of the same title, attributed to the Severus of Antioch, while E. Amato rightly recognized in it the text of the above mentioned ethopoeia by Basilakes. Adriana Pignani, an excellent researcher, failed to notice this manuscript, see E. Amato, An Unpublished Ethopoea of Severus of Alexandria, GRBS 46, 2006, p. 67.

${ }^{118}$ Recently, a translation of both of the progymnasmata on the subject (besides the ethopoeia, diegema must also be added: Niceforo Basilace, Progymnasma, XXIII, ed. Pignani; Nikephoros BAsilakes, Narration, XVI, ed. BENeKer - Gibson, p. 56-59) has been released along with a comprehensive study of the mythographical materials by Stratis PAPAioAnnou, On the Stage of Eros: Two Rhetorical Exercises by Nikephoros Basilakes, [in:] Theatron. Rhetorische Kultur..., p. 357-376.

${ }^{119}$ Cf. Niceforo Basilace, Progymnasma, XXIII, 2, ed. Pignani, p. 99, 281: mentre Amore la constringeva ad andar contro la legge di natura; Nikephoros BAsIlakes, Narration, XVI, 1, ed. BeNeKeR - Gibson, p. 57: Love compelled her to transgress against nature. Eros' strict responsibility for incest is Basilakes' innovation, cf. S. Papaionnnou, On the Stage..., esp. p. 364-366. It is another, besides Pasiphaë, example of god's amorality.

${ }^{120}$ Niceforo Basilace, Progymnasma, LI, 5-21, ed. Pignani, p. 208; Nikephoros Basilakes, Ethopoeia, XXII, 1-2, ed. BENEKER - Gibson, p. 280-283.
} 


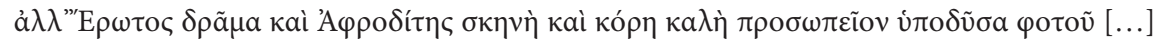

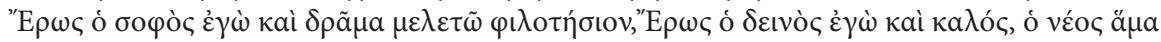

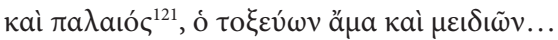

Ma è una rappresentazione d'Amore, è una scena di Afrodite, una bella fanciulla rivestita della maschera di albero. [...] Eros il poeta son io e preparo un dramma d'amore, Eros il terribile son io e bello, nuovo e antico ad un tempo, colui che lancia il dardo e insieme sorride... ${ }^{122}$

But it is a drama of Love, a stage for Aphrodite, a beautiful girl, who put on the mask [prosoppeion] of a tree [...]. I, the wise Love, rehearse a drama of love, I, the clever and beautiful Love, who am both young and old, who both shoots the bow and smiles... ${ }^{123}$

Rather, she is a drama of Eros and Aphrodite's stage. She is a beautiful girl than has put on the mask [prosoppeion] of a tree [...]. I am Eros, the wise one, and I stage a performance [drama] of love. I am Eros, the skillful one and the beautiful, the young one as well as old, sending forth my arrows while also smiling... ${ }^{124}$

Basilakes ambivalently uses the dual meaning of the word drama as a love adventure, and at the same time as its literary development ${ }^{125}$. It connects the level of almost modern metaphor with the level of stage realism (бкпvท́ [stage], mask), which undoubtedly creates an allusion to romance and its recitation as part of the theatron as the most adequate form for this type of subject. One can imagine Nikephoros reciting these words of Eros at a meeting of the literary circle: he would then perform in an excitingly double role. However, Basilakes uses the metaphor of theatre practice too often and too freely for that to be a coincidence ${ }^{126}$.

${ }^{121}$ Cf. depiction of Eros in Sosthenes' garden presented above.

${ }^{122}$ Trans. A. Pignani.

${ }^{123}$ Trans. J. Beneker and C.A. Gibson.

${ }^{124}$ Trans. S. Papaioannou, On the Stage..., p. 362. Each translation has its own advantages.

125 The emergence of the metaphorical meaning of the theatrical terminology, now common in Western culture, was not a trivial matter. On the contrary, the moment of the breakthrough is not known with certainty. Based on documentary sources and not on literary texts, we can only assume that it took place in the last decades of the $5^{\text {th }}$ century. Two examples: (1) P.Oxy 16.1873 (dated: 475-499

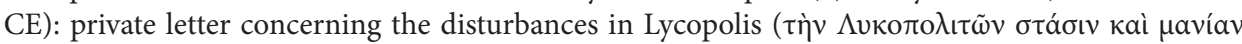

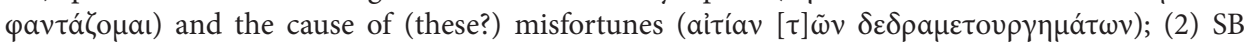
1.5314 (currently linked to 1.5315; dated: 322-642): unspecified private problems, possibly financial

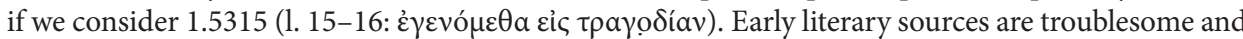
ambiguous because by using references that are "tragic" or "dramatic" in the sense of "misfortune", they do so on the basis of comparison, proverb or references. Only private texts, such as correspondence, are generally free of literary culture references and can therefore help to capture the emer-

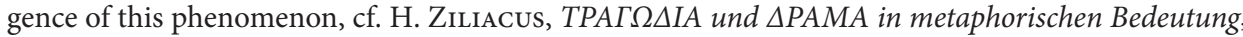
Arc n.s. 2, 1958, p. 217-220.

${ }^{126}$ Nikephoros, In Alex. Arist., IV, 25-28, XVI, ed. Garzya, p. 11, 16; In Ioann. ep., XVI, 8-9, XIX,

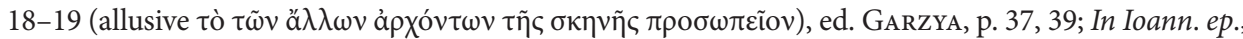
XXIII, 14-15 (paraphrasing the metaphor of Paul, Ad Hebraeos, IX, 11), ed. GARZYA, p. 44; In Iann.

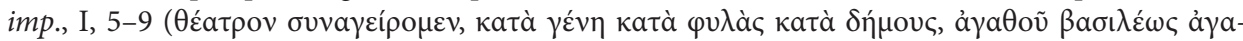

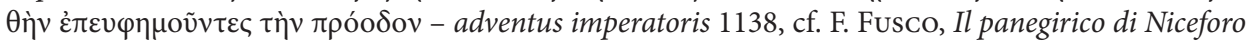


The ethopoeia of Adrastos ${ }^{127}$ features the saying, later so popular in many variants, about "city, a broad stage, rich in misfortunes" 128 ; in monody, death is leaving a "silent stage"129. The verb ' $\theta \varepsilon \alpha \tau \rho i \zeta \omega$ ' (seldom used in Basilakes' times), applied to the delivery of monody $y^{130}$, is a direct reference to acting (gestures, crying, trembling voice). The latter situation may be just as suitable to mean a performance at a meeting at theatron.

\section{Basic convergence lines:}

1. a varied images of Eros and a debate on his nature in the works of theatron poets, as well as a strong presence of often controversial erotic semantics (e.g. Pasiphaë's or Myrrha's casus, militaristic terminology, scenes of violence) in Nikephoros Basilakes' progymnasmata;

a) it has been proven that a similar debate was held on the nature of dreams at that time;

b) both romance and Basilakes agree that sophrosyne is the fundamental arete for maintaining human dignity in the face of Eros' often hostile and destructive actions;

2. Nikephoros Basilakes' frequent and correct application of theatre-related lexicon, as regards both the stage practice (performance) and the metaphor.

On the basis of the above, I can conclude that Nikephoros Basilakes participated in the literary and social discourse of the cultural elites of Constantinople on an equal footing for about twenty years. This would be very difficult, if not impossible, if he was not member of theatron. In addition, his high social standing makes him fully eligible for such an affiliation, and only special circumstances could have prevented him from joining. This did not happen until the mid-1150s, and was most likely the "fault" of Basilakes himself. The autobiographical elements, full of bitterness and sweetened by the rhetoric of self-sufficiency, were written

Basilace per Giovanni Comneno, AFLF.UM 1, 1968, p. 273-306; I. AUGÉ, La reconquête des Comnènes en Orient vue par les panégyristes byzantins, Bi 3, 2001, p. 313-328), ed. GarzyA, p. 49; In Nicolaum

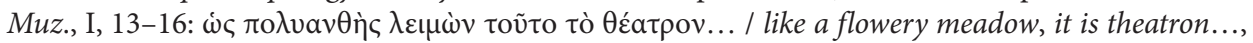
ed. GARZYA, p. 75, followed by a theme of bees akin to the image in HH 5, 10, 5. Unfortunately, recent contribution of P. Rollos ('I grasp, oh, artist, your enigma, I grasp your drama': Reconstructing the Implied Audience of the Twelfth-Century Byzantine Novel, [in:] Fictional Storytelling in the Medieval Eastern Mediterranean and Beyond, ed. C. Cupane, B. KRönung, Leiden-Boston 2016 [= BCBW, 1], p. 463-478), is too general an outline, which only describes l'esprit de siècle.

${ }^{127}$ Niceforo Basilace, Progymnasma, LiI, ed. Pignani, p. 210-216, 356-359; Nikephoros BasiLAKes, Ethopoeia, XXIII, ed. Beneker - Gibson, p. 286-297.

${ }^{128}$ Trans. J. Beneker and C.A. Gibson, p. 289.

${ }^{129}$ Niceforo Basilace, Monodia, II, 173-174, ed. Pignani, p. 259.

${ }^{130}$ Niceforo Basilace, Monodia, I, 120, ed. Pignani, p. 240. 
after these events, so unfortunate for Basilakes; they therefore did not reflect the earlier situation from the time when he wrote his orationes and progymnasmata.

Translated by Katarzyna Gucio

\section{Bibliography}

\section{Primary Sources}

Aristotle, The Athenian Constitution. The Eudemian Ethics. On Virtues and Vices, trans. H. RackHAM, Cambridge Mass.-London 1952 [= Loeb Classical Library, 285].

The Communings with Himself of Marcus Aurelius Antoninus, ed. et trans. C.R. HaInes, LondonNew York 1916 [= Loeb Classical Library, 58].

Diogenes Laertius, Lives of Eminent Philosophers, vol. II, trans. R.D. Hicks, Cambridge Mass.London 1925 [= Loeb Classical Library, 184].

Dreambooks in Byzantium. Six Oneirocritica, trans. et comm. S.M. Oberhelman, Aldershot-Burlington 2008.

Die Erzählung von Alexander und Semiramis, ed. et trans. U. Moennig, Berlin-New York 2004 [= Supplementa Byzantina, 7].

Euripidis fabulae, vol. I, Cyclops, Alcestis, Medea, Hereclidae, Hippolytus, Andromacha, Hecuba, ed. J. Diggle, Oxford 1984 [= Scriptorum Classicorum Bibliotheca Oxoniensis].

Eustathius Macrembolites, De Hysmines et Hysminiae Amoribus Libri XI, ed. M. Marcovich, München-Leipzig 2001.

Four Byzantine Novels, trans. E. JefFreYs, Liverpool 2012 [= Translated Texts for Byzantinists, 1].

Gregorii Nysseni opera, vol. IX.1, ed. G. HeIL, Leiden 1967.

Hermogenis opera, ed. H. RABE, Leipzig 1913.

Ioannes Geometres, [in:] Anecdota graeca, vol. IV, ed. J.A. Cramer, Oxford 1841, p. 266-388.

IoAnnes Tzetzes, Epistulae, ed. P.L. Leone, Leipzig 1972 [= Bibliotheca scriptorum Graecorum et Romanorum Teubneriana].

Libanii Opera, vol. I-XII, rec. R. Foerster, Lipsiae 1903-1927 [= Bibliotheca scriptorum Graecorum et Romanorum Teubneriana].

Marcus Aurelius, Meditations, trans. M. Hammond, London 2006 [= Penguin Classics].

The Meditations of the Emperor Marcus Antoninus, ed. et trans. A.S.L. FARQuHARson, Oxford 1944 [repr. Oxford 1968].

Michael Psellus, The Essays on Euripides and George of Pisidia and on Heliodorus and Achilles Tatius, ed. A.R. Dyck, Wien 1986 [= Byzantina Vindobonensia, 16].

Michaīl Akominatou tou chōniatou ta sōzomena, vol. I-II, ed. S.P. LAmpros, Athēna 1879-1880.

Michel Italikos, Lettres et discours, ed. P. Gautier, Paris 1972 [= Archives de l'Orient chrétien, 14].

Niceforo Basilace, Progimnasmi e monodie, ed. A. Pignani, Napoli 1983 [= Byzantina et Neohellenica Neapolitana, 10].

Nicephori Basilacae Orationes et Epistulae, ed. A. Garzya, Leipzig 1984.

Niketas Eugenianos, Drosilla and Charikles. A Byzantine Novel, trans. et ed. J.B. Burton, Wauconda 2004. 
Platonis opera, vol. II, rec. J. Burnet, Oxonii 1967.

Plutarchi vitae parallelae, vol. II.2, rec. K. ZIEGLER, Lipsiae 1968.

Poème allégorique de Méliténiote, ed. E. Miller, "Notices et extraits des manuscrits de la Bibliothèque impériale et autres bibliothèques" 19, 2, 1857, p. 1-138.

The Rhetorical Exercises of Nikephoros Basilakes. Progymnasmata from Twelfth-Century Byzantium, ed. et trans. J. Beneker, C.A. Gibson, London-Cambridge Mass. 2016 [= Dumbarton Oaks Medieval Library, 43].

Le roman de Callimaque et de Chrysorrhoé, ed. et trans. M. Pichard, Paris 1956.

Der Roman des Konstantinos Manasses. Überlieferung, Rekonstruktion, Textausgabe der Fragmente, ed. O. MazaL, Wien 1967 [= Wiener byzantinistische Studien, 4].

Romanzi cavallereschi bizantini, ed. C. Cupane, Torino 1995.

Il Romanzo Bizantino del XII secolo, ed. F. ConcA, Torino 1994 [= Classici greci. Autori della tarda antichità e dell'età bizantina].

Sophoclis fabulae, rec. H. Lloyd-Jones, N.G. Wilson, Oxonii 1990 [= Scriptorum Classicorum Bibliotheca Oxoniensis].

Theodori Prodromi De Rhodanthes et Dosiclis Amoribus Libri IX, ed. M. Marcovich, StutgardiaeLipsiae 1992 [= Bibliotheca scriptorum Graecorum et Romanorum Teubneriana].

Theodori Prodromi Epistulae et Orationes, ed. M.D.J. Op DE Coul, Turnhout 2018 [= Corpus christianorum, Series graeca, 81].

Vie de Sainte Mélanie, trans. D. Gorce, Paris 1962 [= Sources chrétiennes, 90].

Xenophontis opera omnia, vol. I, ed. E.C. Marchant, Oxonii 1900 [repr. Oxonii 1968].

\section{Secondary Literature}

Alexiou M., A Critical Reappraisal of Eustathios Makrembolites' Hysmine and Hysminias, "Byzantine and Modern Greek Studies" 3, 1977, p. 23-43.

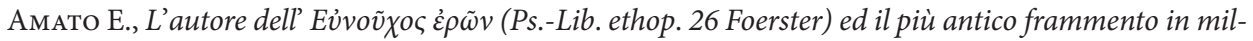
let di etopea d'autore, [in:] Approches de la Troisième Sophistique. Hommages à Jacques Schamp, vol. II, ed. E. Амato, A. Roduit, M. Steinrück, Bruxelles 2005 [= Collection Latomus, 296], p. 3-17.

Амато E., An Unpublished Ethopoea of Severus of Alexandria, "Greek, Roman, and Byzantine Studies" 46, 2006, p. 63-72.

Angold M., Autobiography and Identity: The Case of the Later Byzantine Empire, "Byzantinoslavica. Revue internationale des études byzantines" 60, 1999, p. 36-59.

Augé I., La reconquête des Comnènes en Orient vue par les panégyristes byzantins, "Bizantinistica" 3, 2001, p. 313-328.

Bourbounakis E.C., The End of $\dot{\varepsilon} \pi i \delta \varepsilon ı \xi ı$. Authorial Identity and Authoria Intention in Michael

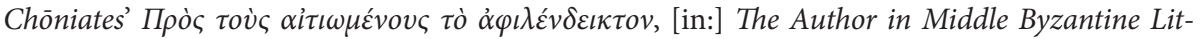
erature. Modes, Functions, and Identities, ed. A. Pizzone, Boston-Berlin 2014 [= Byzantinisches Archiv, 28], p. 201-224.

Bourbouhakis E.C., Rhetoric and Performance, [in:] The Byzantine World, ed. P. Stephenson, London-New York 2010, p. 175-187.

Browning R., Enlightenment and Repression in Byzantium in the Eleventh and Twelfth Centuries, "Past and Present: A Journal of Historical Studies" 69, 1975, p. 3-23. 
Browning R., The Patriarchal School at Constantinople in the Twelfth Century, "Byzantion. Revue internationale des études byzantines" 32, 1962, p. 167-202.

Burgess R., The Accession of Marcian in the Light of Chalcedonia Apologetic and Monophysite Polemic, "Byzantinische Zeitschrift" 86-87, 1993-1994, p. 47-68.

Burton J.B., A Reemergence of Theocritean Poetry in the Byzantine Novel, "Classical Philology" 98, 2003, p. 251-273.

Calofonos G., Dream Interpretation: A Byzantinist Superstition?, "Byzantine and Modern Greek Studies" 9, 1984-1985, p. 215-220.

Cameron A.D.E., The Empress and the Poet: Paganism and the Politics at the Court of Theodosius II, "Yale Classical Studies" 27, 1982, p. 217-289.

Cataldi Palau A., La tradition manuscrite d'Eustathe Makrembolitès, "Revue d'histoire des textes" 10, 1980, p. 75-113.

Christoforatou C., The Iconography of Eros and the Politics of Desire in Komnenian Byzantium, "Enarratio: Publications of the Medieval Association of the Midwest" 12, 2005, p. 71-109.

Conca F., Il romanzo di Niceta Eugeniano: Modelli narrativi e stilistici, "Siculorum Gymnasium. Rassegna semestrale della Facoltà di Lettere e Filosofia dell'Università di Catania” 39, 1986, p. 115-126.

Cox Miller P., Dreams in Late Antiquity. Studies in the Imagination of a Culture, Princeton 1998.

Cupane C.,"E $\rho \omega \varsigma \beta \alpha \sigma \iota \lambda \varepsilon u ́$ c: La figura di Eros nel romanzo bizantino d'amore, "Atti dell'Accademia di Scienze, Lettere e Arti di Palermo" 4 ser., 33, 1973-1974, p. 243-297.

Cupane C., Metamorphosen des Eros. Liebesdarstellung und Liebesdiskurs in der byzantinischen Literatur der Komnenezeit, [in:] Der Roman im Byzanz der Komnenenzeit, ed. P.A. Agapitos, D.R. ReINsCH, Frankfurt am Main 2000 [= Meletemata, 8], p. 25-54.

Cupane C., Orte der Liebe: Bäder, Brunnen und Pavillons zwischen Fiktion und Realität, "Byzantinoslavica. Revue internationale des études byzantines" 69, 2011, p. 167-178.

Cupane C., Una passeggiata nei boschi narrativi. Lo statuto della finzione nel 'Medioevo romanzo e Orientale. In margine a un contributo recente, "Jahrbuch der Österreichischen Byzantinistik" 63, 2013, p. 61-90.

Dostálova R., Die byzantinische Theorie des Dramas und die Tragödie Christos Paschon, "Jahrbuch der Österreichischen Byzantinistik" 32, 1982, p. 73-83.

Elsner J., Introduction: The Genres of Ekphrasis, "Ramus: Critical Studies in Greek and Roman Literature" 31, 2002, p. 1-18.

Esbroeck M. von, La pomme de Théodose II et sa réplique arménienne, [in:] Novum Millenium. Studies on Byzantine History and Culture Dedicated to Paul Speck, ed. C. SoDE, S. TAKÁcs, Aldershot 2001, p. 109-111.

Ethopoiia. La représentation de caractères entre fiction scolaire et réalité vivante à l'époque impériale et tardive, ed. Е. Амато, J. Sснамp, Salerno 2005.

Foskolou V., Decoding Byzantine ekphraseis on Works of Art. Constantine Manasses's Description of Earth and Its Audience, "Byzantinische Zeitschrift" 111, 2018, p. 71-102.

Fournet J.-L., Une éthopée de Caïn dans le Codex des Visions de la Fondation Bodmer, "Zeitschrift für Papyrologie und Epigraphik" 92, 1992, p. 253-266.

Fusco F., Il panegirico di Niceforo Basilace per Giovanni Comneno, "Annali della Facoltà di Lettere e Filosofia, Università di Macerata" 1, 1968, p. 273-306.

Galatariotou C., Eros and Thanatos: A Byzantine Hermit's Conception of Sexuality, "Byzantine and Modern Greek Studies" 13, 1989, p. 95-137. 
Galatariotou C., Travel and Perception in Byzantium, "Dumbarton Oaks Papers" 47, 1993, p. 221-241.

Garland L., 'Be Amorous, But Be Chaste...': Sexual Morality in Byzantine Learned and Vernacular Romance, "Byzantine and Modern Greek Studies" 14, 1990, p. 62-120.

Garzya A., Fin quando visse Niceforo Basilace?, "Byzantinische Zeitschrift” 64, 1971, p. 301-302.

Garzya A., Il "Prologo" di Niceforo Basilace, "Bollettino del Comitato per la preparazione dell'edizione nazionale dei classici greci e latini” n.s. 19, 1971, p. 55-71.

Garzya A., Intorno al Prologo di Niceforo Basilace, "Jahrbuch der Österreichischen Byzantinistik" 18,1969 , p. 57-71.

Garzya A., Literarische und rhetorische Polemiken der Komnenenzeit, "Byzantinoslavica. Revue internationale des études byzantines" 34, 1973, p. 1-14.

Garzya A., Ovide, Nicéphore Basilakès et le mythe de Pasiphaé, "Latomus" 26, 1967, p. 477-479.

Garzya A., Precisazioni sul processo di Niceforo Basilace, "Byzantion. Revue internationale des études byzantines" 40, 1970, p. 309-316.

Garzya A., Un lettré du milieu du XII siècle: Nicéphore Basilakès, "Revue des études sud-est européennes" 8, 1970, p. 611-621.

Garzya A., Une rédaction byzantine du mythe de Pasiphaé, "Le Parole e le idee" 9, 1967, p. 222-226.

Goldhill S., What is Ekkphrasis for?, "Classical Philology” 102, 2007, p. 1-19.

Greek Fiction, ed. J.R. Morgan, R. Stoneman, London-New York 1994.

Grünbart M., Female Founders - Das Konzept: Zu Stiftungshandlungen in der Byzantinischen Welt, "Wiener Jahrbuch für Kunstgeschichte" 60, 2012, p. 21-28.

Grünbart M., 'Tis love that has warm'd us. Reconstructing Networks in $12^{\text {th }}$ Century Byzantium, "Revue belge de philologie et d'histoire" 83, 2, 2005, p. 301-313.

Hagen H.-M., 'HӨолоьí $\alpha$ Zur Geschichte eines rhetorischen Begriffs (Diss., Universität zu ErlangenNürnberg 1966).

HÖRANDNER W., Der Prosarhythmus in der rhetorischen Literatur der Byzantiner, Wien 1981 [= Wiener byzantinistische Studien, 16].

Horna K., Die Epigramme des Theodoros Balsamon, "Wiener Studien. Zeitschrift für klassische Philologie und Patristik" 25, 1903, p. 165-217.

Hunger H., Die hochsprachliche profane Literatur der Byzantiner, vol. II, München 1978 [= Handbuch der Altertumswissenschaft, 12: Byzantinisches Handbuch, 5].

Hunger H., Die Makremboliten auf byzantinischen Bleisiegeln und in sonstigen Belegen, "Studies in Byzantine Sigillography" 5, 1998, p. 1-28.

Jefreeys E., The Comnenian Background to the Romans d'Antiquité, "Byzantion. Revue internationale des études byzantines" 50, 1980, p. 455-486.

Jefreeys E., The Labours of the Twelve Months in Twelfth-century Byzantium, [in:] Personification in the Greek World. From Antiquity to Byzantium, ed. E. STAFford, J. Herrin, Aldershot 2005, p. 309-324.

Jefreneys E., The Sebastokratorissa Eirene as Literary Patroness: the Monk Iakovos, "Jahrbuch der Österreichischen Byzantinistik" 32, 1982, p. 63-71.

Jefreeys E., The Sebastokratorissa Irene as Patron, "Wiener Jahrbuch für Kunstgeschichte" 60, 2012, p. $177-194$.

Jenkins R.J.H., The Hellenistic Origins of Byzantine Literature, "Dumbarton Oaks Papers" 17, 1963, p. 37-52. 
Jouanno C., Les Jeunes filles dans le roman byzantin du XII siècle, [in:] Les Personnages du roman grec. Actes du colloque de Tours, 18-20 novembre 1999, ed. B. Pouderon, C. Hunzinger, D. KASPRZYK, Lyon 2001, p. 329-346.

Jouanno C., Nicétas Eugénianos, un héritier du roman grec, "Revue des études grecques" 102, 1989, p. 346-360.

Kaldellis A., Hellenism in Byzantium. The Transformations of Greek Identity and the Reception of the Classical Tradition, Cambridge 2007.

Kalogeras N., Education Envisioned or The Miracle of Learning in Byzantium, "Byzantinoslavica. Revue internationale des études byzantines" 64, 2006, p. 111-124 (= "Zeitschrift für antikes Christentum" 13, 2009, p. 513-525).

Kazhdan A., Bemerkungen zu Niketas Eugenianos, "Jahrbuch der Österreichischen Byzantinischen Gesellschaft" 16, 1967, p. 101-117.

KoтŁowsкa A., Herakles w bizantyńskiej refleksji poetyckiej. Studium przypadku, "Vox Patrum. Antyk Chrześcijański” 35, 2015, p. 293-296.

Laiou A., The Role of Women in Byzantine Society, "Jahrbuch der Österreichischen Byzantinistik" 31, 1981, p. 233-260.

Lampsidis O., Zur Sebastokratorissa Eirene, "Jahrbuch der Österreichischen Byzantinistik" 34, 1984, p. 91-105.

Lettre-traité de Pierre-Daniel Huet sur l'origine des romans, éd. F. GÉGou, Paris 2005.

Littlewood A.R., An 'Ikon of the Soul': the Byzantine Letter, "Visible Language" 10, 1976, p. 197-226.

Littlewood A.R., Romantic Paradises: The Role of the Garden in the Byzantine Romance, "Byzantine and Modern Greek Studies" 5, 1979, p. 95-114.

Littlewood A.R., The Symbolism of the Apple in Byzantine Literature, "Jahrbuch der Österreichischen Byzantinistik" 23, 1974, p. 33-59.

MacAlister S., Aristotle on the Dream: A Twelfth-Century Romance Revival, "Byzantion. Revue internationale des études byzantines" 60, 1990, p. 195-212.

MacAlister S., Byzantine Developments, [in:] Greek Fiction, ed. J.R. Morgan, R. Stoneman, London-New York 1994, p. 275-287.

MacAlister S., Byzantine Twelfth-century Romances: a Relative Chronology, "Byzantine and Modern Greek Studies" 15, 1991, p. 175-211.

Macrides R., Magdalino P., The Architecture of Ekphrasis: Construction and Context of Paul the Silentiary's Poem on Hagia Sophia, "Byzantine and Modern Greek Studies" 12, 1988, p. 47-82.

Magdalino P., The Empire of Manuel I Komnenos, 1143-1180, New York 1993.

Magdalino P., Eros the King and the King of "Amours": Some Observations on "Hysmine and Hysminias", "Dumbarton Oaks Papers" 46, 1992, p. 197-204.

Magdalino P., In Search of the Byzantine Courtier: Leo Choirosphaktes and Constantine Manasses, [in:] Byzantine Court Culture from 829 to 1204, ed. H. Maguire, Washington 1997, p. 161-165.

Maguire H., Truth and Convention in Byzantine Descriptions of Works of Art, "Dumbarton Oaks Papers" 28, 1974, p. 111-140.

Maisano R., Antonio Garzya bizantinista, [in:] L'Antico e la sua eredità. Atti del Colloquio internazionale di studi in onore di Antonio Garzya (Napoli, 20-21 settembre 2002), ed. U. CRIscuolo, Napoli 2004, p. 195-198.

MaIsano R., La clausola ritmica nella prosa di Niceforo Basilace, "Jahrbuch der Österreichischen Byzantinistik" 25, 1976, p. 87-104. 
Marciniak P., Byzantine Theatron - A Place of Performance?, [in:] Theatron. Rhetorische Kultur in Spätantike und Mittelalter / Rhetorical Culture in Late Antiquity and the Middle Ages, ed. M. Grünbart, Berlin-New York 2007 [= Millennium-Studien. Studien zu Kultur und Geschichte des ersten Jahrtausends n. Chr. / Studies in the Culture and History of the First Millennium C.E., 13], p. 277-285.

Morgan J.R., Make-Believe and Make Believe: the Fictionality of the Greek Novel, [in:] Lies and Fiction in the Ancient World, ed. C. Gill, T.P. Wiseman, Exeter 1993, p. 175-229.

Mullett M., Aristocracy and Patronage in the Literary Circles of Comnenian Constantinople, [in:] The Byzantine Aristocracy, IX to XIII Centuries, ed. M. Angold, Oxford 1984 [= BAR. International Series, 221], p. 173-197.

Mullett M., Rhetoric, Theory and the Imperative of Performance: Byzantium and Now, [in:] Rhetoric in Byzantium. 35 th Spring Symposium of Byzantine Studies, ed. E. JefFreYs, Farnham 2003 [= Society for the Promotion of Byzantine Studies Publications, 11], p. 151-160.

Nilsson I., Erotic Pathos, Rhetorical Pleasure: Narrative Technique and Mimesis in Eumathios Makrembolites' "Hysmine \& Hysminias", Uppsala 2001 [= Studia Byzantina Upsaliensia, 7].

Nilsson I., Nyström E., To Compose, Read, and Use a Byzantine Text: Aspects of the Chronicle of Constantine Manasses, "Byzantine and Modern Greek Studies" 33, 2009, p. 42-60.

Op De Coul M.D.J., The Letters of Theodore Prodromus and Some Other $12^{\text {th }}$ Century Letter Collections, "Medioevo Greco" 9, 2009, p. 231-239.

Opstall E.M. van, On the Threshold. Paul the Silentiary's Ekphrasis of Hagia Sophia, [in:] Sacred Thresholds. The Door to the Sanctuary in Late Antiquity, ed. E.M. van Opstall, Leiden-Boston 2018 [= Religions in the Graeco-Roman World, 185], p. 31-65.

Papaioannou S., On the Stage of Eros: Two Rhetorical Exercises by Nikephoros Basilakes, [in:] Theatron. Rhetorische Kultur in Spätantike und Mittelalter / Rhetorical Culture in Late Antiquity and the Middle Ages, ed. M. GrünBart, Berlin-New York 2007 [= Millennium-Studien. Studien zu Kultur und Geschichte des ersten Jahrtausends n. Chr. / Studies in the Culture and History of the First Millennium C.E., 13], p. 357-376.

Penella R.J., The "Progymnasmata" in Imperial Greek Education, "The Classical World" 105, 2011, p. 77-90.

Pizzone A., Anonymity, Dispossession and Reappropriation in the Prolog of Nikephoros Basilakes, [in:] The Author in Middle Byzantine Literature. Modes, Functions, and Identities, ed. A. Pizzone, Boston-Berlin 2014 [= Byzantinisches Archiv, 28], p. 225-243.

Polemis I.D., A Note on the Praefatio of Nikephoros Basilakes, "Byzantinische Zeitschrift" 94, 2001, p. 605-607.

Poljakova S.V., K voprosu o datirovke romana Evmatija Makremvolita, “Византийский временник" / "Vizantijskij vremennik" 30, 1969, p. 113-123.

Poljakova S.V., O chronologičeskoj posledovatel’nosti romanov Evmatija Makremvolita i Feodora Prodroma, "Византийский временник" / "Vizantijskij vremennik" 32, 1971, p. 104-108.

Puchner W., Zum "Theater" in Byzanz, [in:] Fest und Alltag in Byzanz, ed. G. Prinzing, D. Simon, München 1990, p. 11-16, 169-179 (notes).

Rapp C., Storytelling as Spiritual Communication in Early Greek Hagiography: The Use of Diegesis, "Journal of Early Christian Studies" 6, 1998, p. 431-448.

Rнову A., Ioannes Tzetzes als Auftragsdichter, “Graeco-Latina Brunensia” 15, 2010, p. 155-170.

Rнову A., Verschiedene Bemerkungen zur Sebastokratissa Eirene und zu Autoren in ihrem Umfeld, "Nea Rhōmë" 6, 2009, p. 305-336. 
Rollos P., Amphoteroglossia. A Poetics of the Twelfth-Century Medieval Greek Novel, Cambridge 2005.

Rollos P., 'I grasp, oh, artist, your enigma, I grasp your drama': Reconstructing the Implied Audience of the Twelfth-Century Byzantine Novel, [in:] Fictional Storytelling in the Medieval Eastern Mediterranean and Beyond, ed. C. CupANE, B. KRöNUNG, Leiden-Boston 2016 [= Brill's Companions to the Byzantine World, 1], p. 463-478.

Sathas K., Istorikon dokimion peri tou theatroukai tēs mousikēs tōn Byzantinōn ètoi eisagōgē eis to Krētikōn theatron, Benetia 1878 [repr. Athēna 1979].

Scotт R., From Propaganda to History to Literature: The Byzantine Stories of Theodosios' Apple and Marcian's Eagles, [in:] Byzantine History as Literature, ed. R. MACRIDEs, London 2010, p. 115-133.

Thévenaz O., Auctoris nomina Sapphus: noms et création d'une persona littéraire dans l'Héroïde XV ovidienne, [in:] Onomastique et intertextualité dans la littérature latine. Actes de la journée d'étude tenue à la Maison de l'Orient et de la Méditerranée - Jean Pouilloux, le 14 mars 2005, Lyon 2009 [= Collection de la Maison de l'Orient Méditerranéen Ancien. Série philologique, 41], p. 121-142.

Weвв R., Ekphraseis of Buildings in Byzantium: Theory and Practices, "Byzantinoslavica. Revue internationale des études byzantines" 69, 2011, p. 20-32.

Weвв R., The Progymnasmata in Practice, [in:] Education in Greek and Roman Antiquity, ed. Y. LeE Too, Leiden-Boston 2001, p. 289-316.

Wendel C., Die TAПEINOTH $\Sigma$ des griechischen Schreibermönches, "Byzantinische Zeitschrift" 43, 1950, p. 259-266.

Xenophontos S., Resorting to Rare Sources of Antiquity: Nikephoros Basilakes and the Popularity of Plutarch's Parallel Lives of Twelfth-Century Byzantium, "Parekbolai. An Electronic Journal for Byzantine Literature" 4, 2014, p. 1-12.

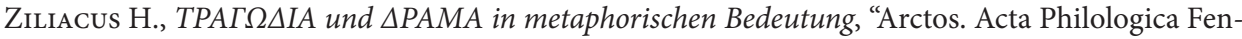
nica" n.s. 2, 1958, p. 217-220.

Abstract. The article analyzes the rhetorical output of Nikephoros Basilakes, focusing on his use of scenic terminology and the psychological interpretation of myths. The conclusions substantiate the theory that Nikephoros had been part of the imperial theatron before his downfall in the mid-1150s.

Keywords: Byzantine novel, ekphrasis, ethopoeia, Nikephoros Basilakes, Pasiphaë, theatre in Byzantium.

Anna Kotłowska

Adam Mickiewicz University in Poznań

Faculty of History

ul. Uniwersytetu Poznańskiego 7

61-614 Poznań, Poland

anna.kot@amu.edu.pl 